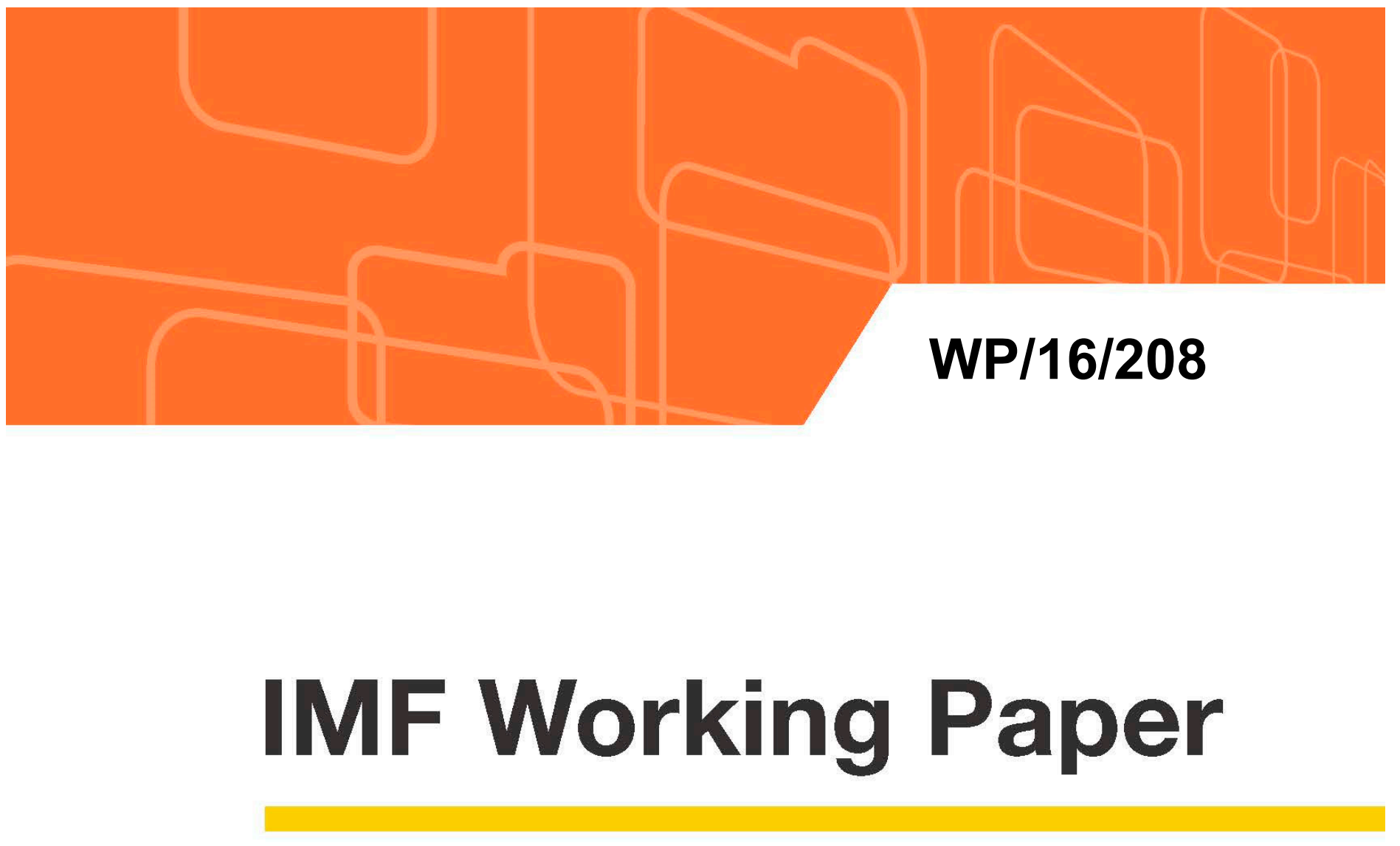

\title{
Dominican Republic: Sectoral Financial Positions and Macroeconomic Vulnerabilities
}

\author{
by Svetlana Cerovic and Jose Saboin
}

IMF Working Papers describe research in progress by the author(s) and are published to elicit comments and to encourage debate. The views expressed in IMF Working Papers are those of the author(s) and do not necessarily represent the views of the IMF, its Executive Board, or IMF management. 


\title{
IMF Working Paper
}

Western Hemisphere Department

\author{
The Balance Sheet Approach to the Dominican Republic: \\ Sectoral Financial Positions and Macroeconomic Vulnerabilities ${ }^{1}$ \\ Prepared by Svetlana Cerovic and Jose Saboin \\ Authorized for distribution by Valerie Cerra
}

October 2016

\begin{abstract}
IMF Working Papers describe research in progress by the author(s) and are published to elicit comments and to encourage debate. The views expressed in IMF Working Papers are those of the author(s) and do not necessarily represent the views of the IMF, its Executive Board, or IMF management.
\end{abstract}

\begin{abstract}
This paper examines the financial position of the key sectors of the Dominican Republic. It contributes to macroeconomic surveillance by identifying financial interlinkages and vulnerabilities through the balance sheet approach. The balance sheet of the economy has been weakening, particularly in foreign currency, due to persistent fiscal deficits. Risks arising from weaker foreign currency position, however, seem to be mitigated by long-term maturities on government debt and increasing accumulation of foreign currency assets. Given the strong links of the rest of the economy with the public sector, network analysis suggests that while the financial position of the other sectors of the economy is stronger, they could be adversely affected in an external stress scenario. Exposures to public sector are particularly pronounced in the domestic financial system (directly) and households (indirectly, through pension funds).

JEL Classification Numbers: F30, F34, H63
\end{abstract}

Keywords: balance sheet approach, net financial position, Dominican Republic, financial interlinkages

Author's E-Mail Address: SCerovic@imf.org; JSaboin@imf.org

\footnotetext{
${ }^{1}$ We thank Aliona Cebotari, Valerie Cerra, Frank Fuentes, Przemek Gajdeczka, Francesco Grigoli and Metodij Hadzi-Vaskov for helpful comments and suggestions.
} 


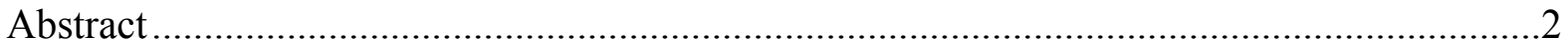

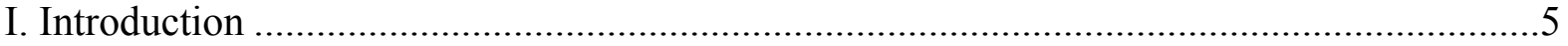

II. The Balance Sheet Approach in the Recent Literature ....................................................5

III. A Brief Overview of Macro-Financial Developments.............................................6

IV. Balance Sheet Analysis..........................................................................................

A. Data and Methodology .............................................................................

B. Role of the 2003 Crisis in Shaping Sectoral Balance Sheets ..................................8

C. Aggregate Balance Sheet 2005-2014 ............................................................10

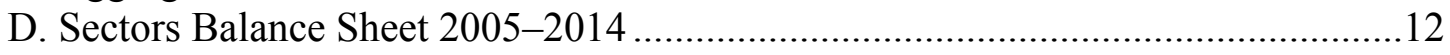

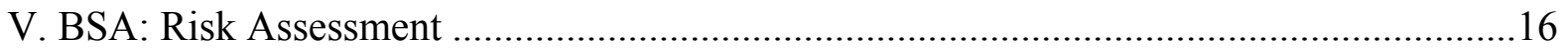

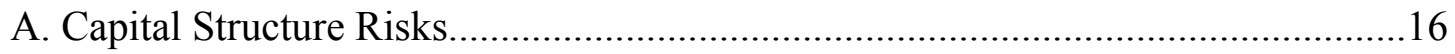

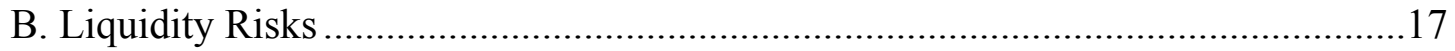

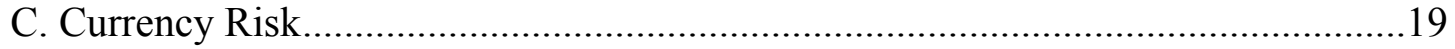

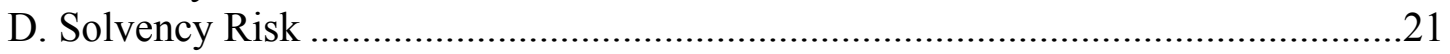

E. The Transmission Channels ............................................................................22

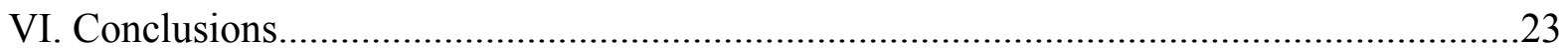

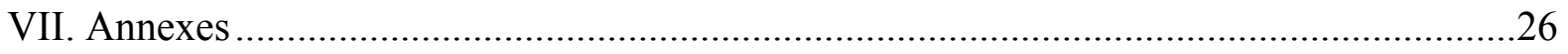

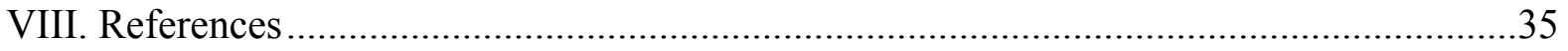

Tables

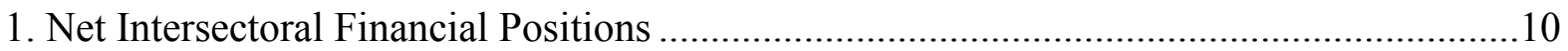

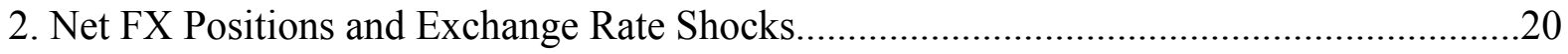

3. Net FX Positions and the 2003 Exchange Rate Shock ...............................................21

Figures

1. BCRD: Assets and Liabilities ...................................................................................

2. Other Depositary Corporations (banks): Assets by Sector .......................................... 9

3. Total Financial Assets and Net Financial Positions .......................................................11

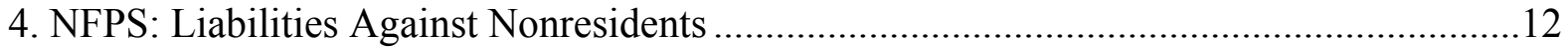

5. NFPS: Net Financial Position vis-à-vis the Financial System ......................................13

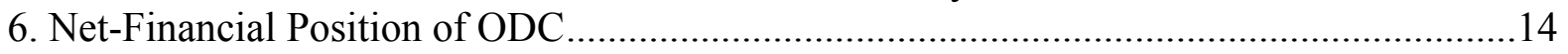

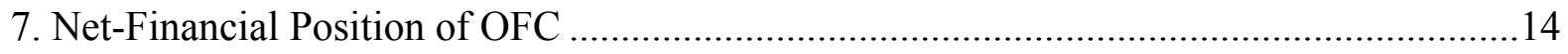

8. OFC: Net-Financial Position vis-à-vis the rest of the Economy .....................................15

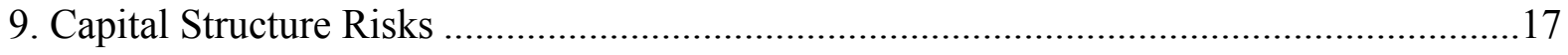


10. Nonfinancial Public Sector: Liquidity Risks …….........................................................18

11. Private Sector: Liquidity Risks .............................................................................19

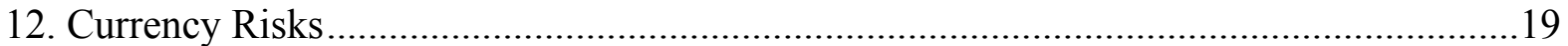

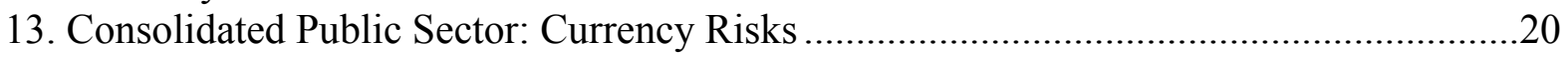

14. Network Map of Intersectoral Linkages ......................................................................... 


\section{INTRODUCTION}

The history of financial crises in emerging markets highlighted the need for a closer attention to vulnerabilities arising from sectoral balance sheets of an economy. Many crises emerged from accumulation of different balance sheet mismatches ${ }^{1}$ of subsectors of the economy (like the public sector, banks or corporate sector) that were quickly transmitted to the rest of the economy through financial linkages among them. To help better understand such financial crises, as well as to deeper examine macroeconomic vulnerabilities, the Balance Sheet Approach (BSA) was developed in the IMF and has been applied to a number of country cases. ${ }^{2}$ The BSA analyzes the vulnerabilities of sectors and transmission mechanisms among them. Assessing mismatches in balance sheets of different sectors in the economy helps understand how shocks can affect the liquidity or solvency position of one sector and how they could be transmitted to others and through the overall economy. Balance sheet analysis is especially useful for surveillance purposes, since it helps detect vulnerabilities that may not be evident in aggregate data.

We provide an overview of sectoral balance sheet developments in the Dominican Republic over the last ten years in order to identify how balance sheet vulnerabilities in one sector could spill over into other sectors. We look at the composition and size of assets and liabilities of the main sectors and their inter-linkages. Particularly, we examine the stocks of assets and liabilities in the country's sectoral balance sheets, the distribution of these across sectors, the types of assets and their funding sources.

The remainder of the paper is organized as follows. Section II briefly reviews the literature on the BSA. Section III provides a background of macroeconomic developments in the Dominican Republic over the last decade. Section IV describes the balance sheet of the economy and its subsectors during the last ten years, while Section V is devoted to analysis, focusing on identifying potential vulnerabilities. Section VI concludes with a summary of our findings.

\section{The Balance Sheet Approach in the Recent Literature}

The BSA was developed after the financial crises of the late 1990s as an analytical tool to detect vulnerabilities that traditional macroeconomic flow indicators proved unable to explain. Unlike the more traditional analysis that looks at flows over a defined period of time, the BSA looks at stocks at a certain point in time. While the analysis of sectoral balance sheets was used in the development of financial crises models, in particular "third generation" models, the more thorough analysis of interlinkages was initially proposed by Allen at al. (2002), and it is increasingly being applied to a number of country cases. Allen et al. (2002) highlight the role that financial balance sheets played during Asian crisis and the importance of monitoring assets and liabilities by sectors, in terms of size, quality and

\footnotetext{
${ }^{1}$ Mismatches are caused by disparities in the composition of a balance sheet. Such mismatches could be related -but not limited to- maturity, currency and solvency. For a detailed explanation of concepts see Allen et al (2002).

${ }^{2}$ Allen et al., “A Balance Sheet Approach to Financial Crisis”, IMF Working Paper WP02/21.
} 
interlinkages. Analyzing the case of Thailand, the paper showed how weaknesses in one sector were transmitted to other sectors and generated a broader crisis.

The academic literature on "third generation" models of financial crisis ${ }^{3}$ is related to the balance sheet approach. Dornbusch (2001), for instance, focuses on balance sheet mismatches and capital flight. The author underscores that, within the economy, the existence of balance sheet mismatches (in terms of currency and maturity) becomes explosive in case of shocks. While he acknowledges that "bad balance sheets" can last almost indefinitely -provided that net inflows are substantial- he also stresses that if the balance sheet is bad enough, quite small events are sufficient to undermine the funding scenario and trigger a crisis. Looking at previous financial crises, he mentions that well-managed emerging market economies have suffered slowdowns in growth, high interest rates, and currency depreciation while they have not suffered a balance sheet-type crisis, suggesting that the better the balance sheets, the better the ability to absorb shocks to capital flows and trade, without outsized adjustments in exchange rates or interest rates.

Krugman (1999) stresses that even a very clean and prudent banking system may not be enough to protect open economies from crisis if the role of companies' balance sheets is neglected. He, as well as Cespedes at al. (2001), Gertler et al. (2003), Cavallo et al. (2005), underlines the importance of currency mismatches in transmitting the shocks through the economy and contributing to a crisis. According to this literature, financial vulnerability expressed though week balance sheets- exacerbates the response of exchange rates to interest rate shocks, and makes contractions in domestic output more persistent. Similarly, Jeanne and Zettelmeyer (2002) show that a currency mismatch in the balance sheet can magnify the impact of shocks that had little to do with a balance sheet originally. They also find that balance sheet vulnerabilities place tight constraints on the capacity of domestic policies to deal with capital account crisis. The risks stemming from currency mismatches were also analyzed by Calvo et al. (2000), Reinhart et al. (2003), indicating that balance sheet mismatches in different sectors of the economy can limit the degree of exchange rate volatility that central banks are willing to tolerate.

\section{A Brief OVERView OF MaCro-Financial DeVElopments}

Following a decade of strong growth, the Dominican Republic entered into a severe economic crisis at the beginning of 2003. The signs of overheating of the economy associated with fiscal policy slippages, large capital inflows and rapid growth of credit to the private sector arose at the beginning of 2000s. While macroeconomic imbalances were building up, the crisis emerged as the confidence in the banking system was shaken by revelations of massive frauds and accounting malpractices in three banks. To support the banking system and stem a deposit run, the Central Bank (BCRD) granted substantial financial support to banks (around 15 percent of GDP) and issued BCRD certificates to absorb the liquidity injection. The banking crisis triggered a sharp deterioration in economic conditions reflected in capital outflows and loss in foreign reserves, significant currency depreciation, acceleration of inflation, and surge of public debt.

\footnotetext{
${ }^{3}$ Refers to models developed after the Asian crises of 1997, which incorporates balance sheet effects.
} 
Since mid-2004 until 2008, in the context of IMF financial program, the commitment of the new government to prudent fiscal and monetary policies, important structural reforms, and a favorable external environment, contributed to a significant improvement in economic and financial conditions. Tight fiscal policy led to a non-financial public sector (NFPS) surplus. The net financial position of the government improved with public debt-to-GDP ratio being reduced by almost one-half, from about 60 percent in 2003 to 35 percent in 2008 . The exchange rate stabilized, and inflation declined from over 40 percent in 2003 to 4.5 percent in 2008. BCRD managed to recover loss of foreign reserves. Financial sector reforms that were focused on bank recapitalization together with institutional, legal and regulatory changes, helped commercial banks recover and strengthen their position.

However, the global financial crisis in 2008 and the weak external demand affected the economy and threatened to jeopardize some of the achievements from the 2004-2008 period. Depressed foreign and domestic demand affected overall GDP. Difficulties in domestic and foreign capital markets forced tightening of the fiscal position, while monetary policy was drastically loosened, though insufficiently to offset the effect of fiscal tightening on growth. In order to preserve the achievements of the previous several years, and in light of large gross financing needs, the authorities requested an IMF financial program in 2009. The program helped the country achieve strong recovery through the countercyclical macroeconomic program. Since 2009, the economy experienced robust growth, with average real GDP growth of 5 percent, one of the highest in Latin America. However, the fiscal consolidation was delayed until 2013, causing a sharp increase of public debt.

The changes in the sectors balance sheets related to above mentioned economic developments will be analyzed in the following sections.

\section{Balance Sheet Analysis}

This section analyzes the aggregate balance sheet of the economy and its subsectors for the period 2005-2014. We will only briefly discuss the effects of the 2003 financial crisis on the financial structure of the economy, as a comprehensive set of data is available only from 2005.

\section{A. Data and Methodology}

The main instrument for this analysis is the balance sheet matrix (Table 1 and Annex 1). The data used in constructing the matrix are the Standard Report Forms (SRF) ${ }^{4}$ for monetary and financial statistics and the International Investment Position (IIP) for the external counterpart, reported by countries to the IMF. The economy is disaggregated into six sectors:

(i) the central bank (BCRD);

(ii) the non-financial public sector (NFPS) which includes the central government, state and local governments, public non-financial firms, and social security;

\footnotetext{
${ }^{4}$ In 2004 the IMF introduced the Standard Report Forms which are based on standardizes methodology for compilation, and are designed for countries' reporting of monetary and financial data.
} 
(iii) other depository corporations (ODC) which include commercial banks and other deposit-taking institutions. The structure of this sector in the DR is such that 86 percent relates to commercial banks.

(iv) other financial corporations (OFC) which in the case of the Dominican Republic include only pension funds;

(v) the non-financial private sector which includes non-financial corporations (NFPC), and other domestic resident sector (largely households); the rest of the world or nonresidents.

Within each sector, financial assets and liabilities are decomposed into foreign and domestic currency, and to the extent data were available, by maturity. The net financial position is defined as financial assets minus financial liabilities.

Some data limitations exist. The available IIP data do not allow us to completely distinguish between the assets of NFPC and households. Also, the full breakdown of maturity of assets was not available, limiting our assessment of liquidity risks. While we know that there is a financial link between NFPS and NFPC through bond holding, this segment is not captured.

\section{B. Role of the 2003 Crisis in Shaping Sectoral Balance Sheets}

The 2003 financial crisis significantly changed the overall financial composition of the economy through sectoral interlinkages. The signs of the crisis are still evident in the balance sheets of some sectors, and given its importance, we will briefly explain them here, before we move to more recent developments.

The overall position of the public sector deteriorated with a sharp increase in debt in 2006, once the losses of the banks' bailout were recognized. BCRD's balance sheet expanded due to its large support to banks. The main assets in its balance sheet before the crisis were international reserves and claims on the banking system, while liabilities consisted of banks' reserve requirements and money issued. As the crisis unfolded, the BCRD provided abundant support to distressed banks, which led to a surge in its assets from 10 percent of GDP in 2002 to 23 percent in 2003. Deposit redemptions from banks were initially paid in cash, and later when the banks were resolved, the BCRD honored all legitimate deposits by issuing central bank certificates (Swiston et al 2014). As a result, the BCRD issued securities equivalent to 15 percent of GDP. Once the banks were resolved, the BCRD assumed the assets that were pledged for liquidity support and absorbed the losses as majority of claims were not recovered (Swiston et al 2014). The interest costs of the issued securities and recognition of losses eroded the BCRD financial position, leading to an accumulation of quasi-fiscal deficits over the years. In 2006 the accumulated losses of the central bank were recognized by the government, and they were capitalized as claims to the NFPS. Cumulative losses expressed through these claims to the government represent the main item on the asset side of BCRD balance sheet.

As BCRD continued issuing certificates after the crisis, partly to roll-over the maturing debt, cover the quasi-fiscal deficit, and for liquidity management purposes, the stock of securities has remained high, at around 13 percent of GDP as of end-2014. The holders of these securities are banks, pension funds, as well as private corporations (see Annex II, Figure 3). 


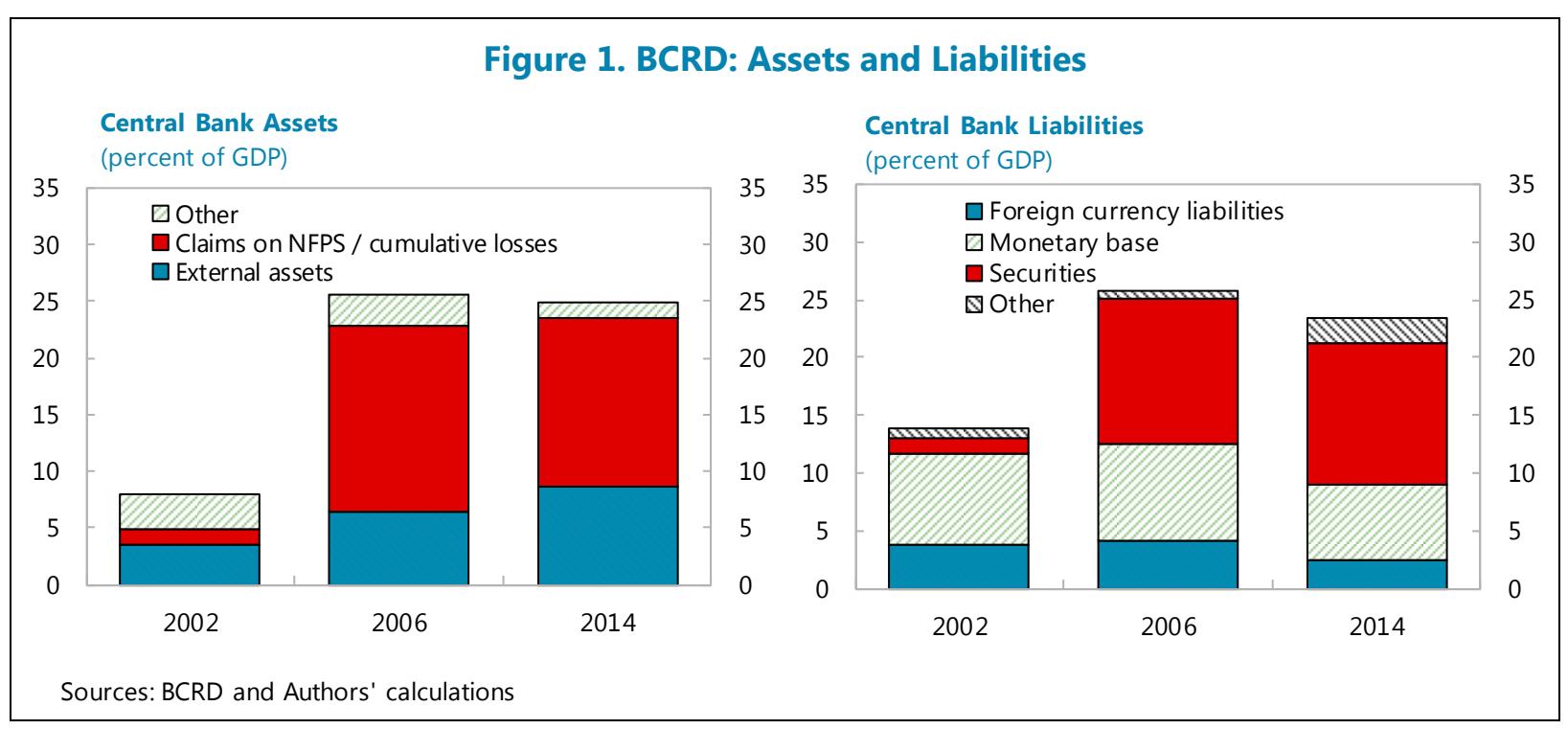

On the banking side (ODC), the crisis led to a contraction of the sector and a decline in assets. The process of cleanup in the financial system that followed, together with reinforced regulation and supervision measures, led to a very gradual recovery with the size of the system (expressed as an asset to GDP ratio) at the end-2014 still below the pre-crisis levels. Moreover, a relatively high interest rate on BCRD securities prompted banks to invest in those instruments, and as a result, claims to the BCRD increased from 13 percent of their total domestic assets before the crisis to 25 percent in 2014. On the other hand, while credit to the private sector have been increasing, its share in bank's assets declined with respect to the pre-crisis period.

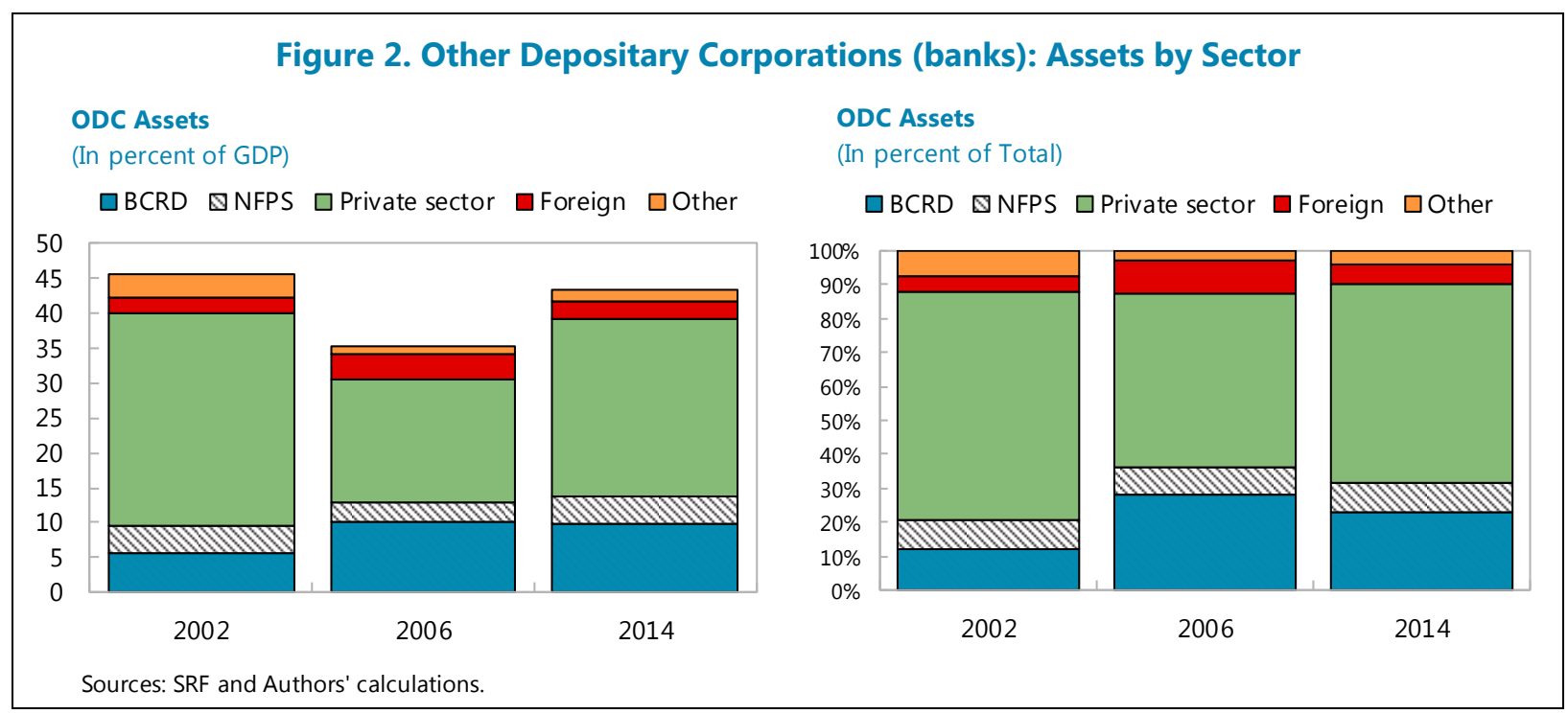




\section{Aggregate Balance Sheet 2005-2014}

The overall financial position of Dominican Republic changed over the last ten years. Gross financial assets of the country increased 12 percentage points of GDP since 2005. The growth was particularly driven by the financial sector, including both ODC and OFC, reflecting strong economic growth coupled with macroeconomic reforms and financial deepening.

Despite the growth of financial assets, the net financial position of the overall economy has significantly worsened, especially since the outbreak of the 2008 global financial crisis. The deterioration is mostly driven by the accumulation of public debt and the resulting worsening of the net financial position of the NFPS. The worsening of the net financial position is especially pronounced in foreign currency. On the other hand, all remaining sectors slightly improved their net financial position (Table 1 and Figure 3).

\begin{tabular}{|c|c|c|c|c|c|c|}
\hline \multicolumn{7}{|c|}{$\begin{array}{r}\text { Table 1. Dominican Republic: Net Intersec } \\
\text { In percent of GDP) } \\
2014\end{array}$} \\
\hline \multirow{3}{*}{$\begin{array}{l}\text { Issuer of liability (debtor) } \\
\text { Holder of liability } \\
\text { (creditor) }\end{array}$} & \multicolumn{2}{|c|}{ Public sector } & \multicolumn{2}{|c|}{ Financial Sector } & \multirow{3}{*}{$\begin{array}{c}\text { Private Sector } \\
\text { Nonfinancial } \\
\text { Private Sector } \\
\text { Net pos. }\end{array}$} & \multirow{3}{*}{$\begin{array}{c}\text { Rest of the World } \\
\text { Nonresidents } \\
\text { Net pos. }\end{array}$} \\
\hline & $\begin{array}{c}\text { Central } \\
\text { bank }^{1}\end{array}$ & $\begin{array}{l}\text { Nonfinancial } \\
\text { public sector }\end{array}$ & $\begin{array}{c}\text { Other depository } \\
\text { corporations }^{1,2}\end{array}$ & $\begin{array}{l}\text { Other financial } \\
\text { corporations }^{2}\end{array}$ & & \\
\hline & Net pos. & Net pos. & Net pos. & Net pos. & & \\
\hline Central bank & & -16.0 & 9.9 & 5.4 & 4.1 & -6.3 \\
\hline In domestic currency & & -16.1 & 8.0 & 5.4 & 4.1 & -0.6 \\
\hline In foreign currency & & 0.1 & 1.9 & 0.0 & 0.0 & -5.7 \\
\hline Nonfinancial public sector & 16.0 & & 2.1 & 6.7 & $\ldots$ & 26.8 \\
\hline In domestic currency & 16.1 & & 1.2 & 6.7 & $\ldots$ & 0.0 \\
\hline In foreign currency & -0.1 & & 0.8 & 0.0 & $\ldots$ & 26.8 \\
\hline Other depository corporations ${ }^{1}$ & -10.1 & -2.1 & & 3.4 & 4.4 & 0.4 \\
\hline In domestic currency & -8.2 & -1.2 & & 3.4 & 1.8 & 0.1 \\
\hline In foreign currency & -1.9 & -0.8 & & 0.0 & 2.6 & 0.3 \\
\hline Other financial corporations & -5.4 & -6.7 & -2.9 & & 9.8 & 0.0 \\
\hline In domestic currency & -5.4 & -6.7 & -2.7 & & 9.8 & 0.0 \\
\hline In foreign currency & 0.0 & 0.0 & -0.1 & & 0.0 & 0.0 \\
\hline Nonfinancial private sector & -4.1 & $\ldots$ & -4.4 & -9.8 & & -4.2 \\
\hline In domestic currency & -4.1 & $\ldots$ & -1.8 & -9.8 & & 0.0 \\
\hline In foreign currency & 0.0 & $\ldots$ & -2.6 & 0.0 & & -4.2 \\
\hline Nonresidents & 6.3 & -26.8 & -0.4 & 0.0 & 4.2 & \\
\hline In domestic currency & 0.6 & 0.0 & -0.1 & 0.0 & 0.0 & \\
\hline In foreign currency & 5.7 & -26.8 & -0.3 & 0.0 & 4.2 & \\
\hline $\begin{array}{l}\text { Sources: Standardized report forms } \\
1 \backslash \text { There are discrepancies between } r \\
2 \backslash \text { There are discrepancies between } r\end{array}$ & $\begin{array}{l}\text { for moneta } \\
\text { reported s } \\
\text { reported } s\end{array}$ & $\begin{array}{l}\text { ary and financial } \\
\text { sectoral positions } \\
\text { sectoral positions }\end{array}$ & $\begin{array}{l}\text { data and International ir } \\
\text { by BCRD and ODC } \\
\text { by ODC and OFC }\end{array}$ & nvestment position & esident data & \\
\hline
\end{tabular}




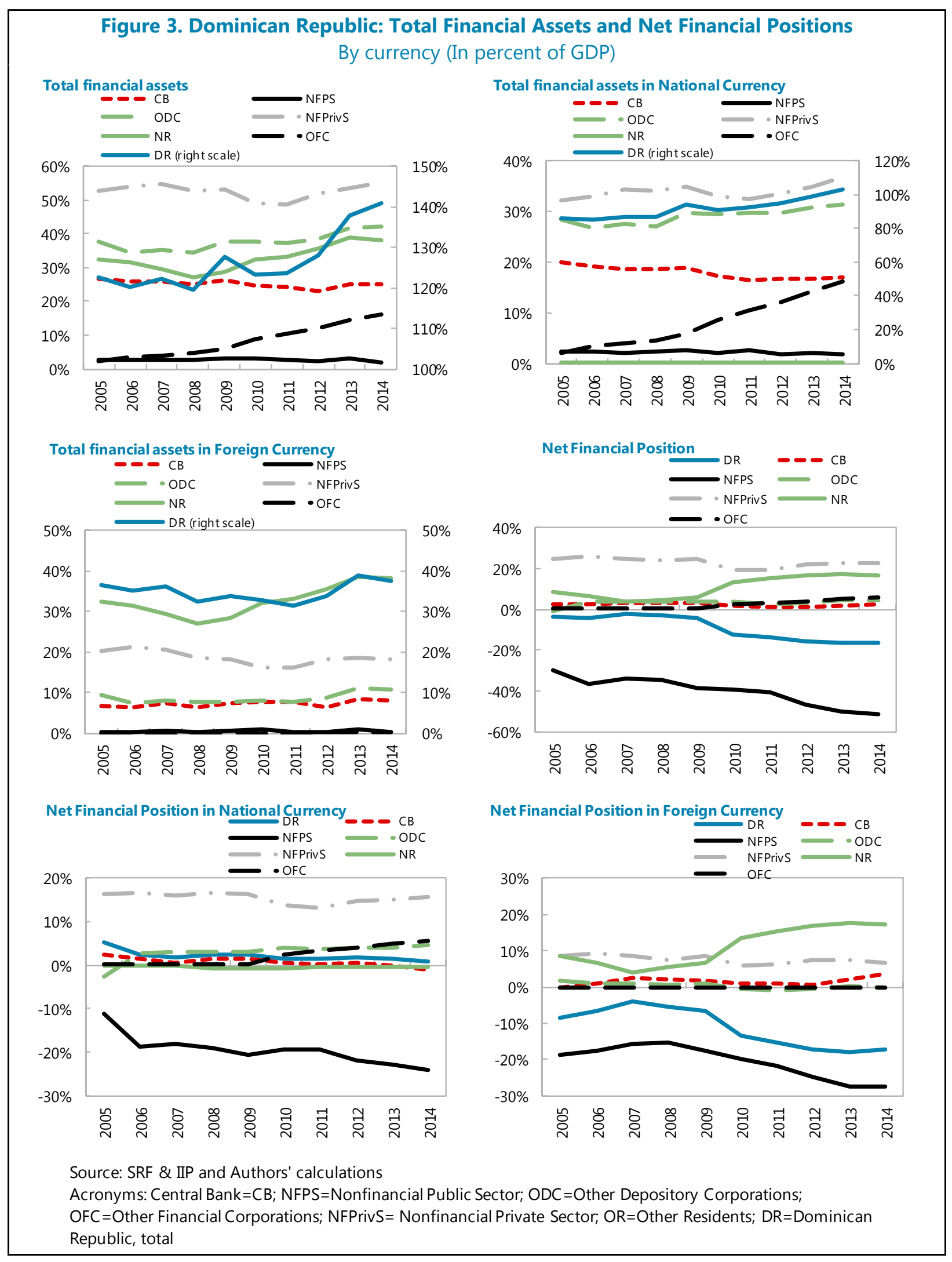




\section{Sectors Balance Sheet 2005-2014}

\section{Public Sector}

\section{Nonfinancial Public Sector}

The balance sheet of the government has worsened, and currently represents the most vulnerable sector in the economy. Liabilities have more than tripled since 2005, reaching 53 percent of GDP in 2014, owing both to the recognition of losses related to 2003 financial crisis, as well as borrowing related to the financing of fiscal deficits.

On the domestic side, commercial banks and pension funds are the main source of government financing. During the global financial crisis in 2008-09, when external conditions tightened, government increased its borrowing from domestic banks. The net financial position improved in 2010-11 but after that it sharply worsened as fiscal deficit notably increased in 2012, and was to a large extent financed through borrowing in foreign currency (Figure 4). At the same time, the increased reliance on foreign financing in recent years led to accumulation of foreign liabilities. This is particularly evident from 2010 onwards, when the Dominican Republic was able to attract substantial resources by issuing sovereign bonds. Around 55 percent of total government debt is held by non-residents.

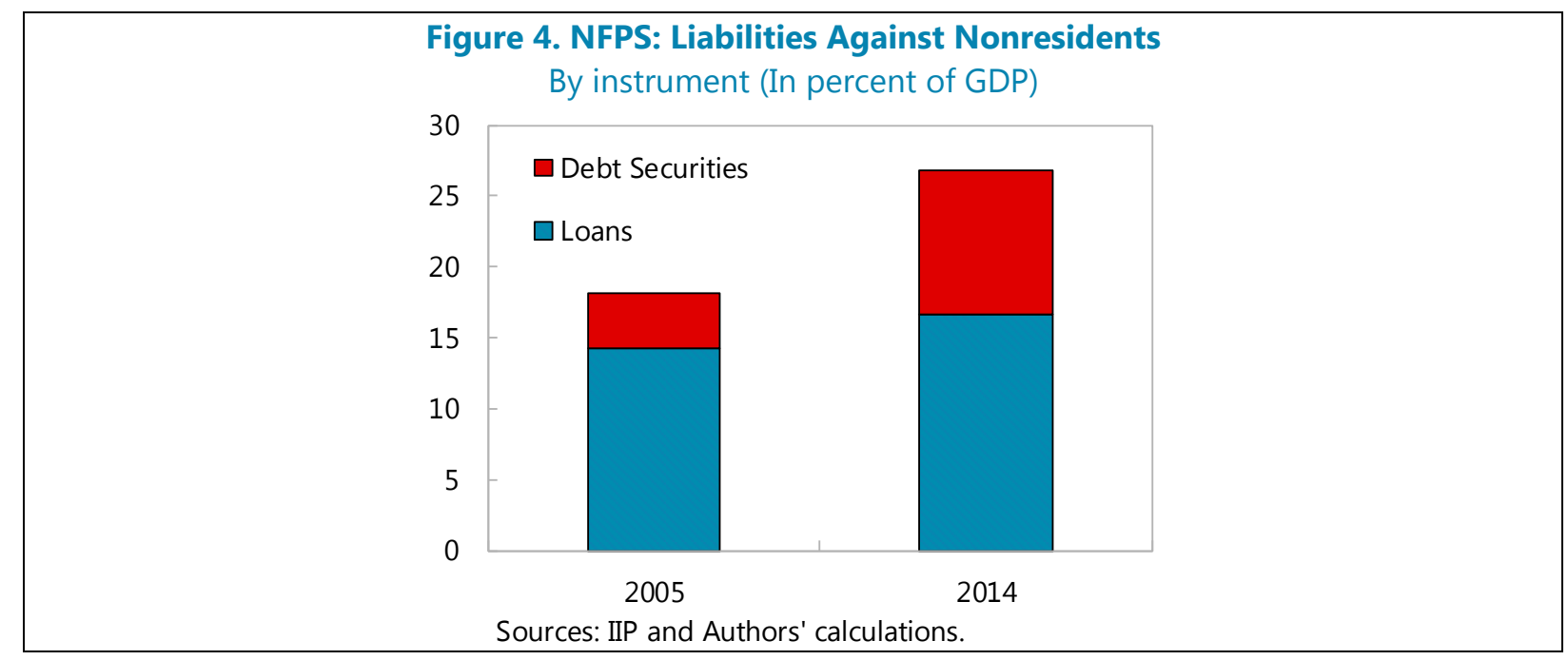




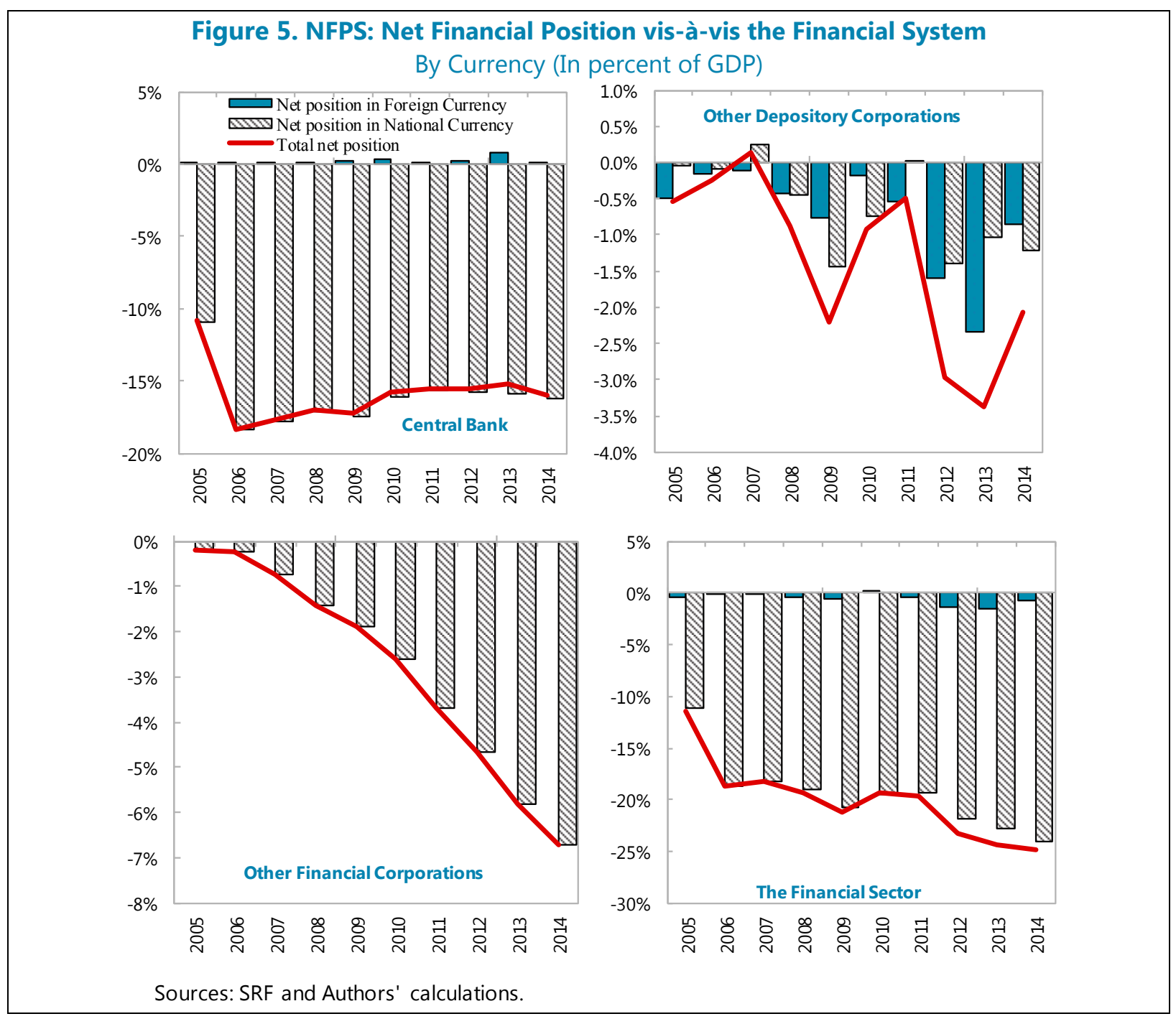

\section{BCRD}

The net financial position of BCRD vis-à-vis nonresidents mostly reflects international reserves and liabilities to the IMF related to previous financial programs. While the global financial crisis did not affect the Bank's balance sheet, as the country managed to mobilize substantial financial resources from international financial institutions, expansionary fiscal and monetary policies in 2012 led to reserves loss and deterioration of the net financial position. In the last two years, the repayment of liabilities to the IMF, as well as strong economic growth and favorable external developments, contributed to the improvement of the net financial position of the BCRD through accumulation of international reserves. (Annex II, Figure 3) 


\section{Other Depository Corporations}

The recognition of losses by the government related to 2003 crisis led to a one-off improvement of the banks' overall net financial position in 2006, which remained broadly stable afterwards (see Annex II, Figures 4 and 5). Banks are mostly financed by private sector (corporations and households) deposits and to a lesser extent by external borrowing. On the assets side, lending to the private sector is the largest in the banks' asset portfolio, but, as discussed above, claims to the BCRD remain high partly due to investments in the central bank's long-term securities. Claims to the government also increased in recent years.

Foreign assets and liabilities represent a small share in banks' balance sheet ( 5 and 7 percent of total assets and liabilities, respectively), and the overall net position in foreign currency has remained

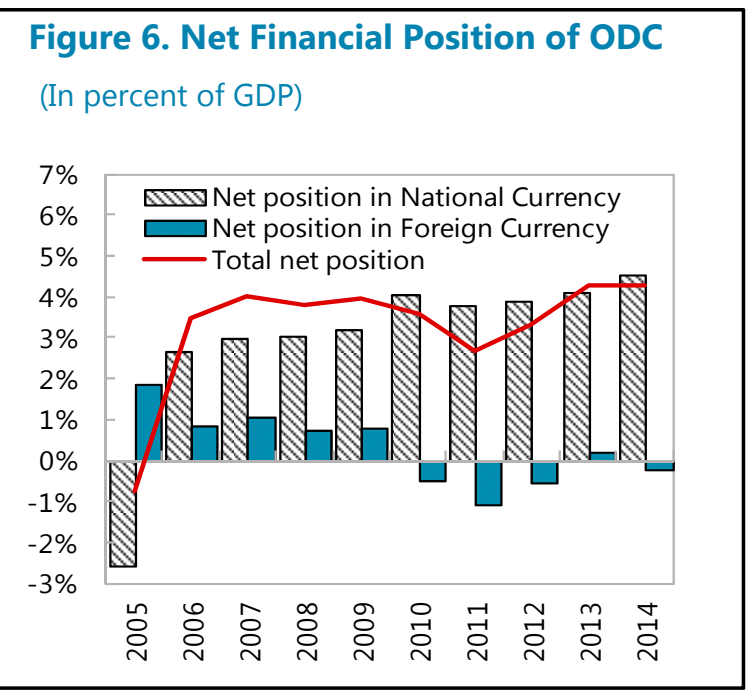
balanced around \pm 0.5 percent of GDP over the last five years.

\section{Other Financial Corporations}

Due to data limitations, OFC are analyzed only through the pension funds (see Figures 7 and 8). However, this does not undermine the overall assessment, given that the rest of the sector is small

Figure 7. Net Financial Position of OFC

The pension system in the Dominican Republic was reformed in 2003 when the system of mandatory savings was introduced. The main sources of financing for pension funds are mandatory contributions of employers and employees. Since the reform took place, contributions to the pension funds have been gradually increasing. As a result, OFC have a negative position (i.e. liabilities) against nonfinancial private sector (including households) that increased from 2.2 percent of GDP in 2005 to almost 10 percent of GDP in 2014 (Figure 8) Here, we do not take into account the actuarial valuation of the pension funds liabilities. . (In percent of GDP)

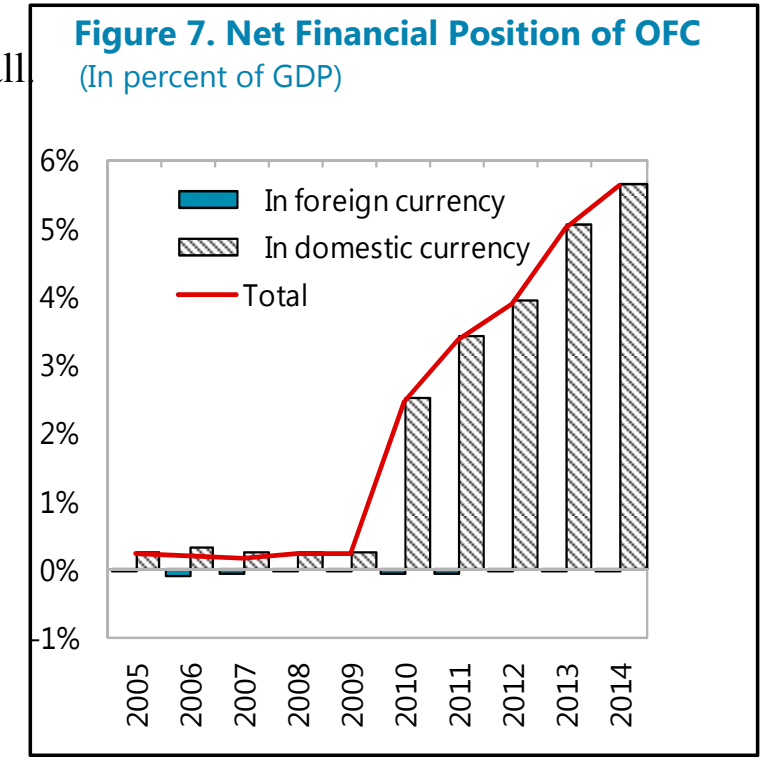

The pension funds represent the fastest growing segment of the financial market. The funds are invested in public debt instruments, and to a lesser extent in bank deposits and certificates, and private debt instruments. The regulation that allows pension funds to invest in government debt instruments was introduced in 2007 with an initial limit of 20 percent of 
total assets to be invested in BCRD instruments and 15 percent in central government bonds. The ceiling on assets allocation dedicated to BCRD securities was raised to 50 percent in 2011 and to 20 percent for central government bonds in 2013. High return of public debt instruments, and limited issuance of corporate bonds led to a concentration of pension funds' assets in government securities up to allowed limits. As a result, OFC net creditor position vis-à-vis the Central Bank increased from 0.2 percent of GDP in 2007 to 5 percent of GDP in 2014.

Similarly, the net credit position vis-à-vis the General Government increased from 0.2 percent to 6.7 percent of GDP. There is a clear preference on pension funds towards investment in BCRD and central government securities, as reflected in net creditor position vis-à-vis bank CDs which only increased by 1.5 percentage points of GDP. At the end of 2014, 66 percent of total assets of pension funds were invested in central bank securities and government bonds, and 32 percent in the banking system. According to the current regulation, pension funds are not allowed to invest in foreign instruments or markets.

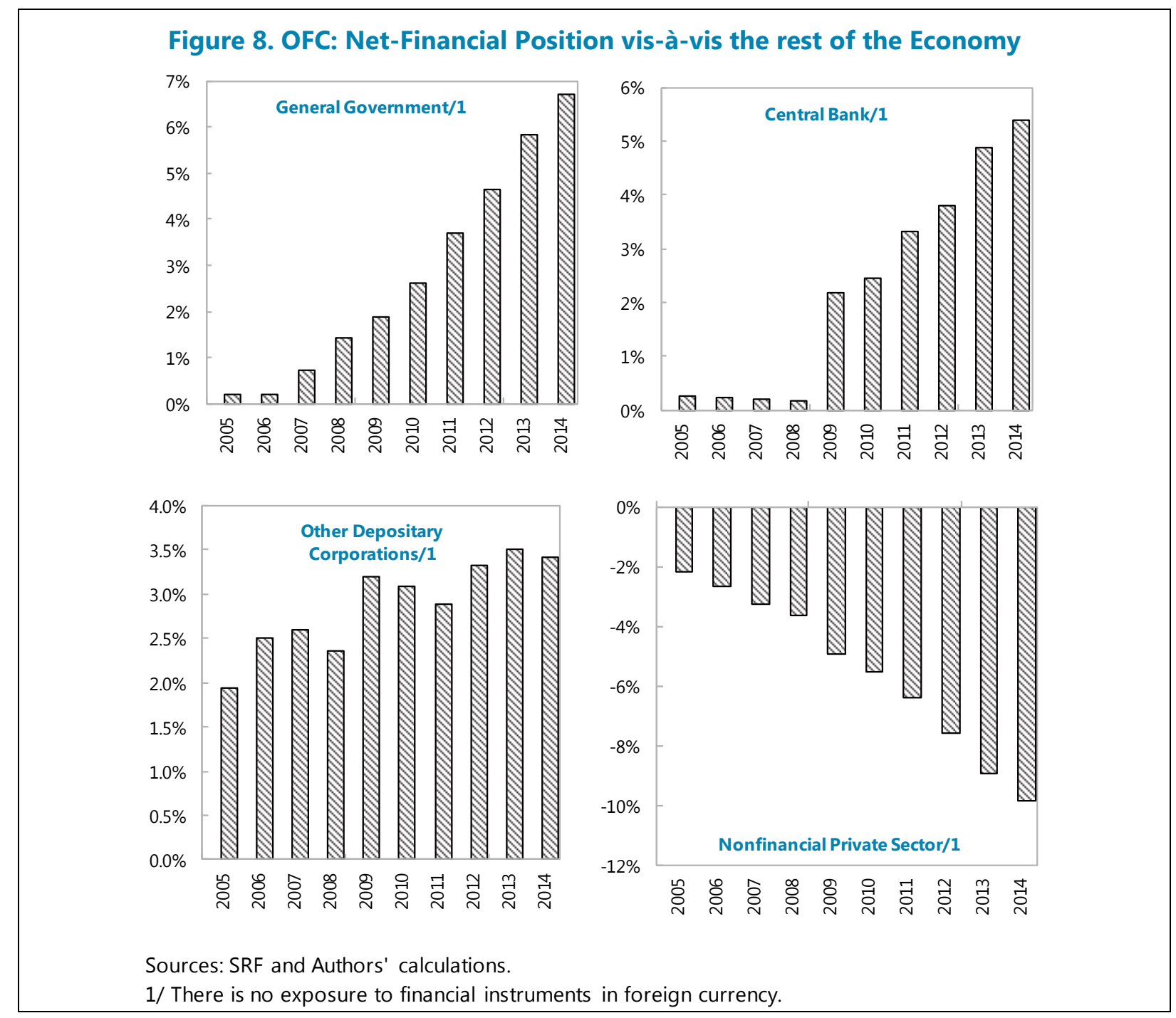




\section{Nonfinancial Private Sector}

At the aggregated level, the nonfinancial private sector has a strong positive position against nonresidents, which deteriorated during global financial crisis, but has been improving since 2011. The improvement in recent years is related to accumulation of deposits abroad, while borrowing remained broadly unchanged. The available IIP data does not allow us to distinguish between the financial position of nonfinancial corporations and households against nonresidents (see Annex II, Figures 6, 7, and 8).

\section{Nonfinancial Corporations}

Though it remained positive during the last ten years, the domestic net financial position of the corporate sector has deteriorated. The deterioration is mostly associated with a reduction of the creditor position against the Central Bank, and to a less extent, with an increase of the borrowing from the banking system. Private corporations decreased their holdings of BCRD securities from 9.6 percent of GDP in 2006 to 4.3 percent of GDP in 2014. Corporations increased their borrowing from the banking system, both in domestic and foreign currency. As a result, the net financial position of the corporate sector in the banking system is slightly negative, but more pronounced in foreign currency. While this debtor position in foreign currency against banks of around 3 percent of GDP could be a source of risk, the overall nonfinancial private sector has accumulated assets abroad -mainly in the form of deposits- of as much as 7.5 percent of GDP, which could provide a buffer in a stress situation scenario (See part V).

\section{Households}

Households are net creditor in the economy. They improved their net creditor position against the financial system significantly, owing, mainly, to an accumulation of assets in the pension funds. Households' net financial position in the banking system remained broadly unchanged and hovered around 4.5 percent of GDP over the period. The net position in domestic currency was broadly balanced while the net foreign currency position remained strong, at around 5 percent of GDP.

\section{BSA: RISK ASSESSMENT}

This section analyzes how various sectors of the economy are exposed to balance sheet risks. Risks associated with: capital structure, maturity mismatches, currency mismatches and solvency, are studied at the aggregated level (the economy against the rest of the world) as well as at the sectoral level (the consolidated public sector, the financial system and the private sector) against the rest (including the rest of the world).

\section{A. Capital Structure Risks}

Capital structure is defined as composition of debt and equity in country's financing. Capital structure mismatch risk results from relying excessively on debt financing rather than equity (Allen et al.). While the Dominican Republic has large foreign liabilities, the share of equity in these liabilities is substantial, helping it to mitigate overall vulnerabilities. Including FDI liabilities (e.g. equity holdings), the country's net external debtor position increased from 36 percent of GDP in 2005 to 61 percent of GDP at the end of 2014. However, excluding FDI 
liabilities, the economy's net debtor position falls to 16 percent of GDP as of 2014, a deterioration of only 9 percentage points of GDP over the last 10 years (Figure 9, chart on the left).

The reason to look at foreign liabilities by excluding FDI is that such equity holdings are by definition state contingent (e.g. with profits and dividends falling in bad times), while debtservice payments generally remain unchanged in bad times, thus decreasing a country's payment capacity. Therefore, while the country has a relatively high negative total net external position (including FDI), it has a moderate negative net external debt position measured as gross external debt minus total external assets. Moreover, since the composition of liabilities has been increasingly moving towards equity instruments (FDI liabilities increased from 48 percent to 54 percent of total external liabilities), the Dominican economy has improved its capital structure (Figure 9, chart on the right).

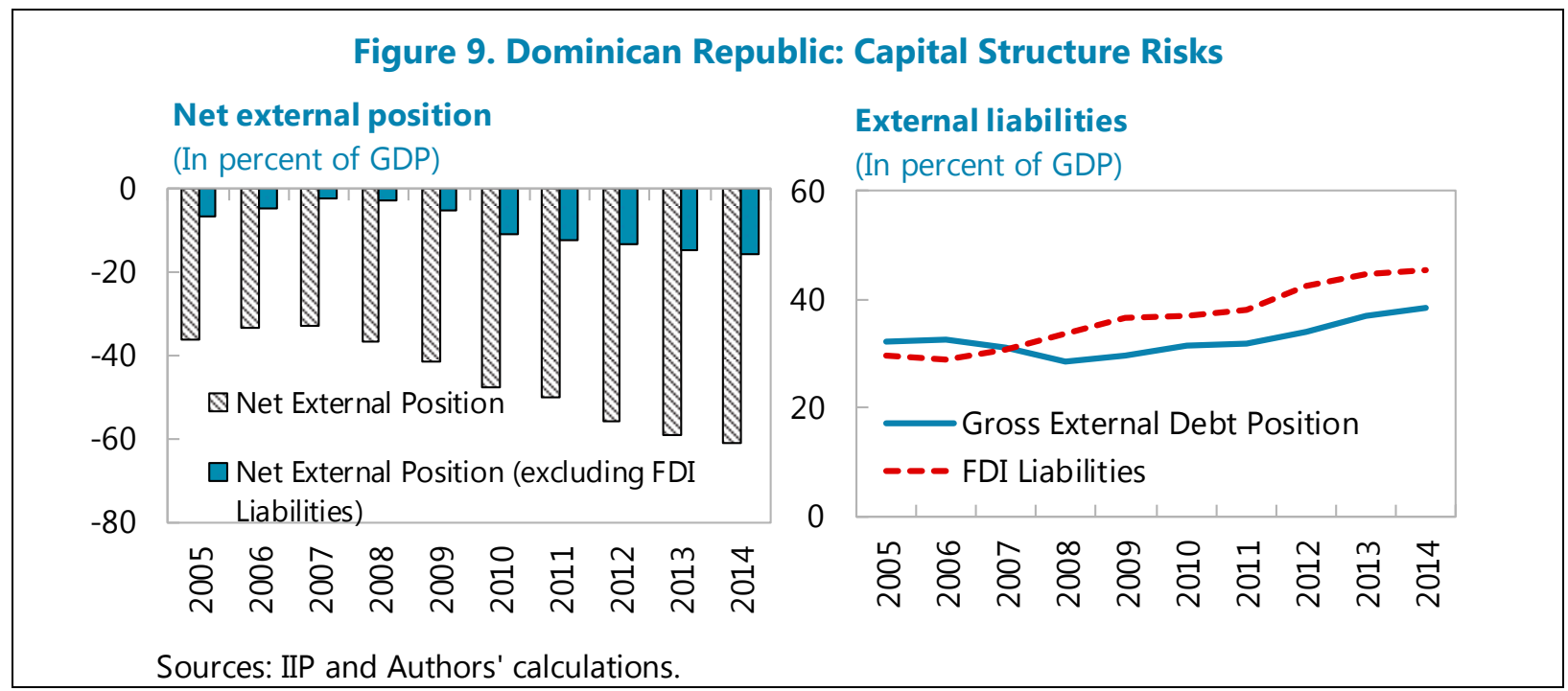

\section{B. Liquidity Risks}

Liquidity risks arise from maturity mismatches in the balance sheet when assets are long term and liabilities are short term, posing difficulties to meet short-term financial obligations. Liquidity risks are therefore assessed by comparing short-term assets to short-term liabilities. The overall economy shows low liquidity risks, with strong short-term net financial position against nonresidents. The position improved over time as a result of the increase of international reserves, new government borrowing with longer maturities, as well as an increase of banks deposits abroad and private sector deposits in FX -relative to their shortterm FX liabilities.

NFPS: The available data indicate that the short-term net financial position of NFPS has improved. In terms of foreign currency, the accumulation of international reserves by BCRD and long maturities of the public sector's external debt (9 years on average) are the main contributors to this improvement. We treat here a liquid part of foreign BCRD reserves as assets that are available for government debt service. Part of foreign reserves related to 
commercial banks reserve requirement is excluded from calculations, as it is assumed that is not affectively available to the authorities.

In domestic currency, due to data availability, we cannot identify short-term liabilities of NFPS. We therefore conservatively assume that all loans borrowed from banks (excluding government bonds) are short-term. Comparing such liabilities to short-term assets indicates that NFPS has a positive short-term net financial position. It is however important to note that this does not imply that available short term assets are enough to meet all budget-related short term liabilities (like any current budgetary spending). Instead, it suggests that government can pay its short term debt from available short term assets. This position has been strengthening over the period of study, as short-term liabilities in domestic currency have decreased by 1 percent of GDP (Figure 10).

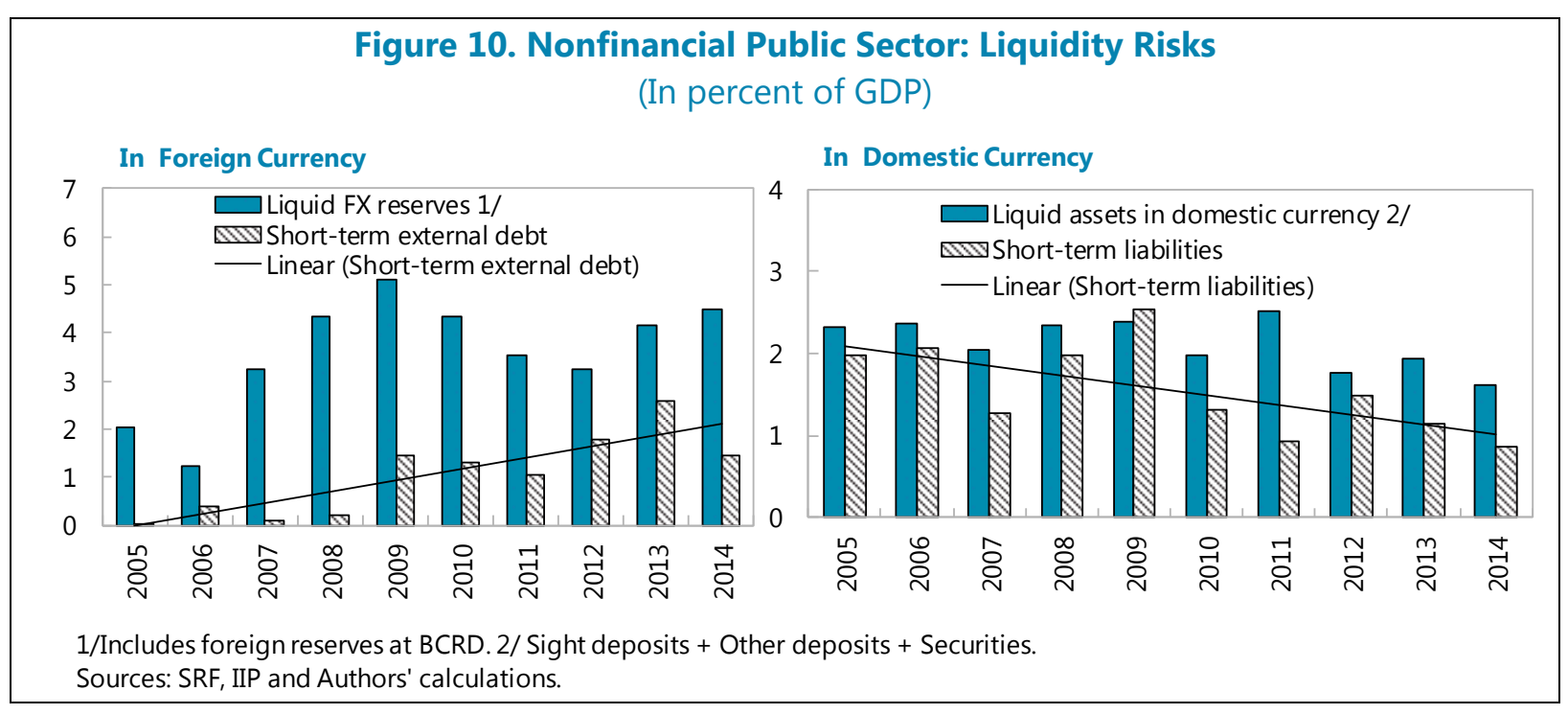

Banks: The available data do not allow us to fully assess the existence of maturity mismatches in the banking system (e.g. the breakdown of maturity on bank loans is not available). In general, assessed through standard financial soundness indicators reported by the authorities, banks appear to be very liquid, sufficiently capitalized and profitable, suggesting limited vulnerabilities to liquidity risk.

Private sector: The overall nonfinancial private sector does not appear vulnerable to liquidity risks ${ }^{6}$. The sector has a strong short-term creditor position ( 4 percent of GDP). The bulk of this short-term net creditor position is related to a net foreign currency position of 3.8 percent of GDP, as the domestic currency position is balanced (see Figure 11). The sector also presents a short-term net creditor position against nonresidents at 1.6 percent of GDP. This position has deteriorated as short-term foreign assets declined after the global financial crisis.

\footnotetext{
${ }^{6}$ Here we conservatively assume all domestic and external loan liabilities and debt securities are short-term.
} 


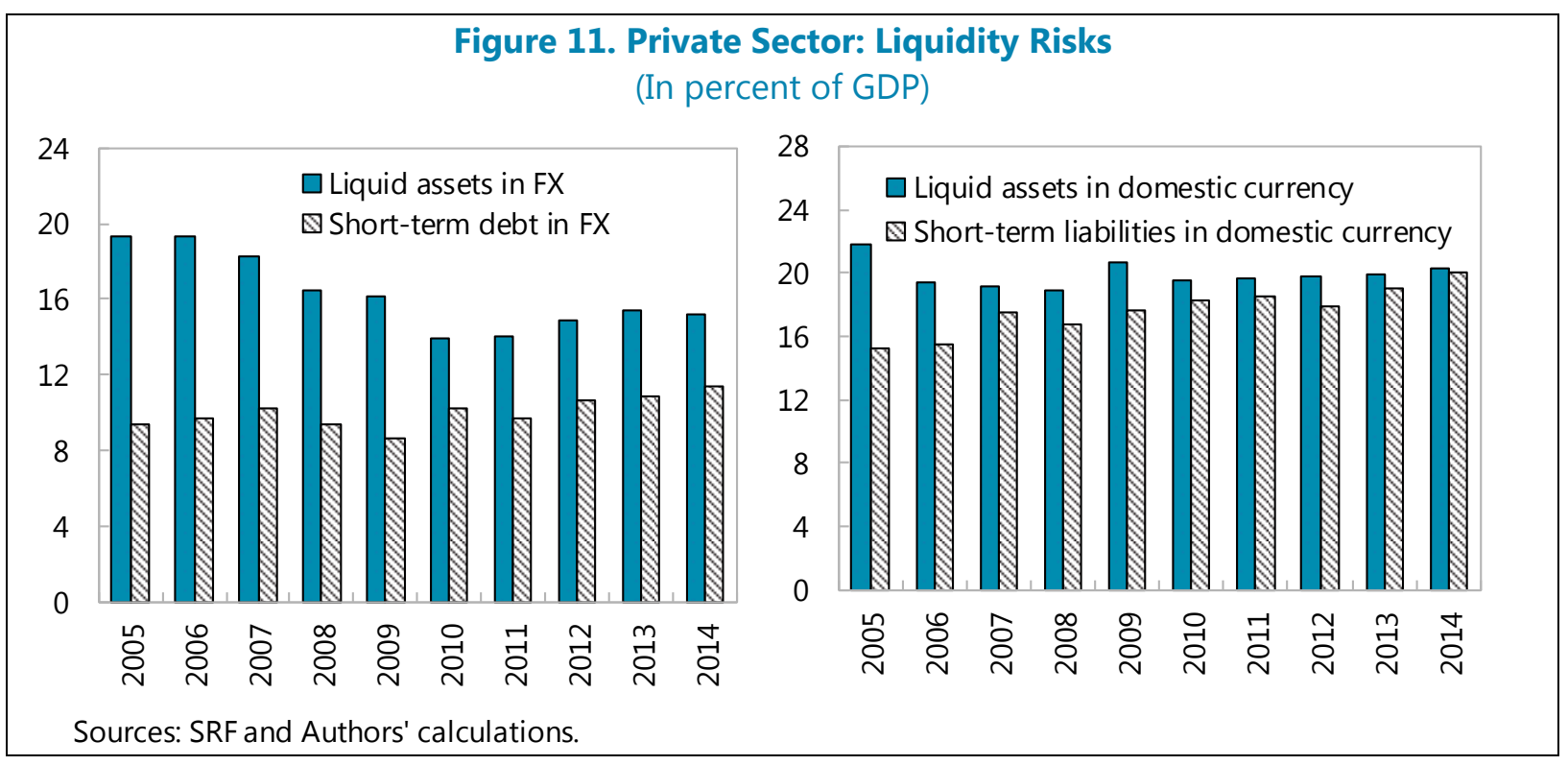

\section{Currency Risk}

Economy: The economy is exposed to currency risks. The country has a net debtor position in foreign currency (expressed as external assets minus external liabilities in FX), which has been deteriorating over the last ten years. The economy's net debtor position in FX - excluding FDI liabilities - has worsened from 7 percent of GDP in 2005 to 15 percent in 2014. This reflects the fact that the increase in the public sector's net external debt was higher than BCRD's and government's combined accumulation of external assets. Including FDI liabilities, the net FX position worsens, from - 32.7 percent of GDP in 2005 to -59.4 percent of GDP in 2014.

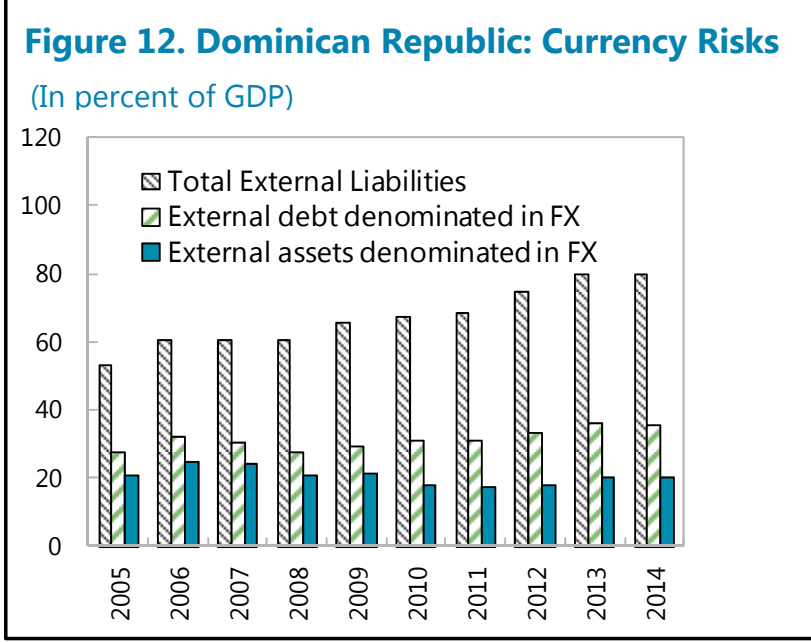

Consolidated public sector (CPS): The sector has a net debtor position in FX of 18.3 percent of GDP 7 . Such position has increased over 2005-2014 period (from 12 percent of GDP) reflecting the accumulation of debt in FX mostly by the Central Government. The assessment of this risk is crucial since the direct impact of a real depreciation on any net foreign currency debtor is on its income and wealth, triggering risks in other sectors.

\footnotetext{
${ }^{7}$ The position increases to 20.2 percent of GDP once multiple banks claims on central bank reserves -related to required reserves on FX deposits- are also taken into account.
} 
Figure 13. Consolidated Public Sector: Currency Risks
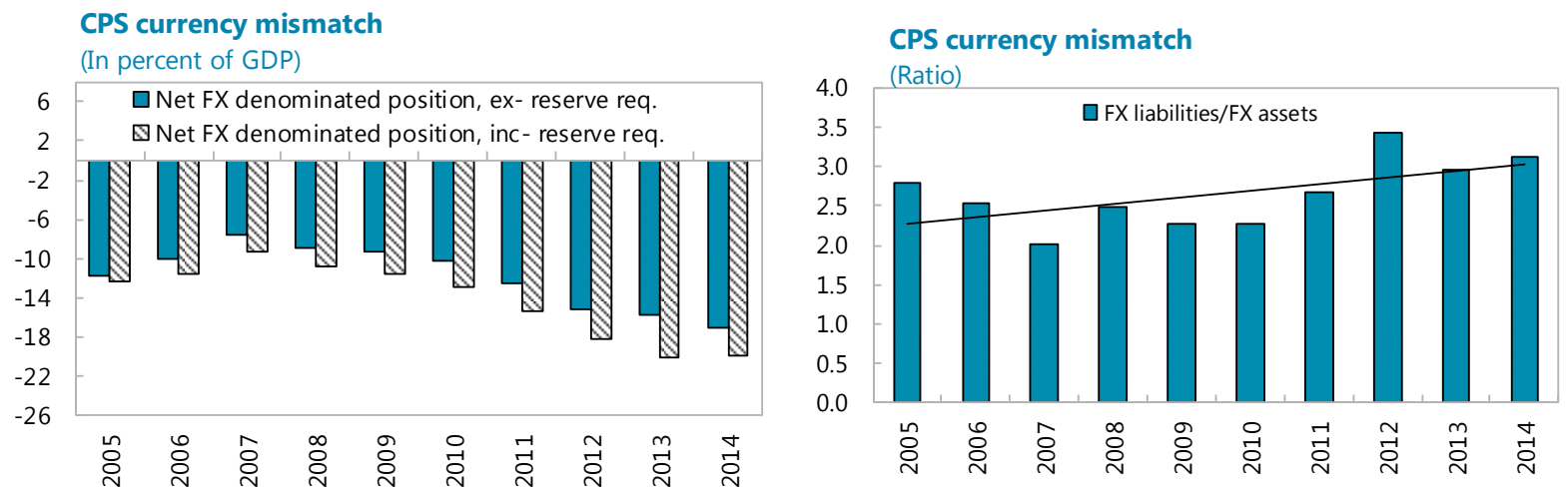

Sources: SRF, IIP and Authors' calculations.

Banks: Banks maintain a close-to-balance overall net FX position, although differences among certain sectors of the economy exist. The 2005-2014 period average is 0.6 percent of GDP and the estimated 2014 position was at -0.2 percent of GDP. ${ }^{8}$ Banks have a negative financial position in FX against households of around 5 percent of GDP. Household deposits in FX have been at around 5.4 percent of GDP on average during the period, and they seem to be the main source of FX lending to private corporations and NFPS. This suggest that corporates may be exposed to notable FX risk, although corporates and households together have a strong liquid asset position abroad (7.5 percent of GDP) that could act as a buffer'.

\section{a) Stress test: currency depreciation scenario}

The NFPS is the most exposed to exchange rate risk. Table 2 shows the direct impact of a negative FX shock on the net positions of the different sectors of the economy.

\begin{tabular}{|c|c|c|c|}
\hline \multicolumn{4}{|c|}{$\begin{array}{l}\text { Table 2. Dominican Republic: Net FX Positions and Exchange Rate Shocks } \\
\text { (In percent of GDP) }\end{array}$} \\
\hline \multirow[b]{2}{*}{ Sector } & \multirow[b]{2}{*}{ End-2014 } & \multicolumn{2}{|c|}{ Loss/Gain } \\
\hline & & $\begin{array}{l}\text { From } 2015 \\
\text { depreciation }\end{array}$ & $\begin{array}{l}\text { From large exchange rate } \\
\text { shock ( } 30 \text { percent) }\end{array}$ \\
\hline Central bank & 3.7 & 0.1 & 1.1 \\
\hline Nonfinancial public sector & -27.5 & -1.1 & -8.3 \\
\hline Financial sector & -0.3 & 0.0 & -0.1 \\
\hline Private sector & 9.3 & 0.4 & 2.8 \\
\hline Vis-à-vis financial sector $1 /$ & 2.6 & 0.1 & 0.8 \\
\hline Vis-à-vis all sectors 2/ & 6.8 & 0.3 & 2.0 \\
\hline \multicolumn{4}{|c|}{ 1/ Includes FX bank credit and deposits. } \\
\hline \multicolumn{4}{|c|}{ 2/ Includes FX bank credit and deposits, and net foreign assets of the private sector. } \\
\hline
\end{tabular}

\footnotetext{
${ }^{8}$ The current financial regulation on the limits on FX open position is relatively relaxed, allowing banks to have an open FX net position of up to 100 percent of capital.

${ }^{9}$ Since IIP data does not distinguish between NFPC and households, the position against nonresidents cannot be disaggregated.
} 
As shown throughout this section, there are two sectors that would be largely affected by an exchange rate shock: the NFPS (negatively) and the private sector (positively). It is important to note however, that whereas the positive impact in the private sector tends to be small (2.8 percent of GDP in the case of 30 percent depreciation) the negative impact on the NFPS could be quite large ( 8.3 percent of GDP). In the case of the depreciation for 2015 of 3.2 percent, the net FX position of the NFPS would deteriorate by 1.1 percent of GDP. Moreover, in the aftermath of the 2003 banking crisis, when the exchange rate depreciated by 79 percent, the net debtor position of NFPS increased by 30 percentage points of GDP (Table 3$)^{10}$. However, as overall direct risk is mitigated by the fact that short-term liabilities are quite small in terms of GDP, looking through the balance sheet effects, the long-term impact of an exchange rate shock to the economy will be through the fiscal channel by increasing public debt, and possibly affecting its trajectory.

Table 3. Dominican Republic: Net FX Positions and the 2003 Exchange Rate Shock

\begin{tabular}{|c|c|c|c|c|}
\hline & \multirow[b]{2}{*}{ End-2002 } & \multirow{2}{*}{$\begin{array}{c}\text { Loss/Gain } \\
\text { From } 2003 \\
\text { depreciation }\end{array}$} & \multirow[b]{2}{*}{ End-2003 predicted } & \multirow[b]{2}{*}{$\begin{array}{c}\text { End-2003 } \\
\text { actual }\end{array}$} \\
\hline & & & & \\
\hline Central bank & -1.1 & -0.8 & -1.9 & -3.6 \\
\hline Nonfinancial public sector & -16.9 & -13.3 & -30.2 & -29.4 \\
\hline Financial sector & 0.5 & 0.4 & 1.0 & 2.7 \\
\hline Private sector & -7.1 & -5.6 & -12.7 & -2.9 \\
\hline Vis-à-vis financial sector 1 / & -1.0 & -0.8 & -1.9 & 0.0 \\
\hline Vis-à-vis all sectors 2/ & -6.1 & -4.8 & -10.8 & -2.9 \\
\hline
\end{tabular}

\section{Solvency Risk}

According to the standard approach to assess solvency, a country as a whole is solvent as long as the present discounted value of all future balances in the current account is sufficient to pay for the country outstanding external liabilities (in GDP terms) ${ }^{11}$. This approach is taken into account by Allen et al (2002) to assess how balance sheet risks apply for a country as whole, as they look at the stock of external liabilities relative to both external financial assets held by residents and the discounted value of future trade surpluses.

One simple (albeit not unique) way to determine the level of the current account balance as percent of GDP that stabilizes the external debt at a benchmark level is defined by the equation:

\footnotetext{
${ }^{10}$ While the predicted result for the NFPS was very similar to what actually happened in 2003 , the differences between actual and predicted results in the rest of the sectors is due to the fact that predicted values just show the impact of a one-off depreciation of the exchange rate in the stock variable, leaving everything else constant. Actual values, on the other hand, register actual developments with the balance sheets during the crisis as explained in section II B.

${ }^{11}$ IMF 2002 and 2006.
} 
$c a^{S}=\frac{g+\pi(1+g)}{(1+g)(1+\pi)} b^{S}$

where $g_{t}$ is the growth rate of real GDP, $\pi$ the rate of inflation, $b^{s}$ the benchmark level of the external debt as percent of GDP, and assuming for simplicity (but without loss of generality) that capital gains, capital transfers and errors and omissions are zero.

The choice of the benchmark $b^{s}$ is a matter of judgment and may reflect a variety of considerations (see, IMF 2006). In this exercise, following Allen et al (2002), we use the level that would be necessary for the economy to maintain the level of external debt as it was in 2014. The economy's growth rate is set at $4.5 \%$ for potential output growth in the medium term while inflation is set to the $4 \%$ target of BCRD.

Table 4 shows that the current account deficit achieved in 2014 (-3.2 percent of GDP) was broadly in line with the level needed to stabilize the external debt at the 2014 level of 38 percent of GDP

\begin{tabular}{|c|c|c|c|}
\hline \multicolumn{4}{|c|}{$\begin{array}{l}\text { Table 4. Dominican Republic: Current Account Sustainability Indicators } \\
\text { (In percent of GDP) }\end{array}$} \\
\hline & \multicolumn{2}{|c|}{ Current levels } & \multirow{2}{*}{$\begin{array}{c}\text { Sustainable level } \\
\text { External Debt at current levels }\end{array}$} \\
\hline & 2013 & 2014 & \\
\hline Current Account (CA) & -4.1 & -3.2 & \multirow{2}{*}{-3.0} \\
\hline 10-year CA & -5.5 & -5.3 & \\
\hline
\end{tabular}

A reversal of the current account deficit to the average of the last ten years would put the external debt on an upward path, therefore continued accumulation of foreign assets and their returns (reserve accumulation), would be important in maintaining macroeconomic stability.

\section{E. The Transmission Channels}

Another way to look at vulnerabilities of the sectoral balance sheet of the economy and potential spillovers in stress events is through the network map of intersectoral linkages. The nodes represent the size of the net financial position of each sector, the thickness of the links between the nodes point to the size of the exposure, and the colors of the links represent the sign of the net position: green for net creditor and red for net debtor position. The direction of exposure between sectors is set to be read clockwise.

As shown in Figure 14, the NFPS has a large direct negative exposure against non-residents. The exposure against the BCRD is also large, and, as mentioned above, related to the recognition of losses of the 2003 banking crisis, as well as the accumulation of quasi-fiscal deficits. The financing from pension funds and banks is also evident. The network clearly shows that NFPS sector is the most vulnerable in the economy due to its large debtor position. 
Figure 14. Dominican Republic: Network Map of Intersectoral Linkages

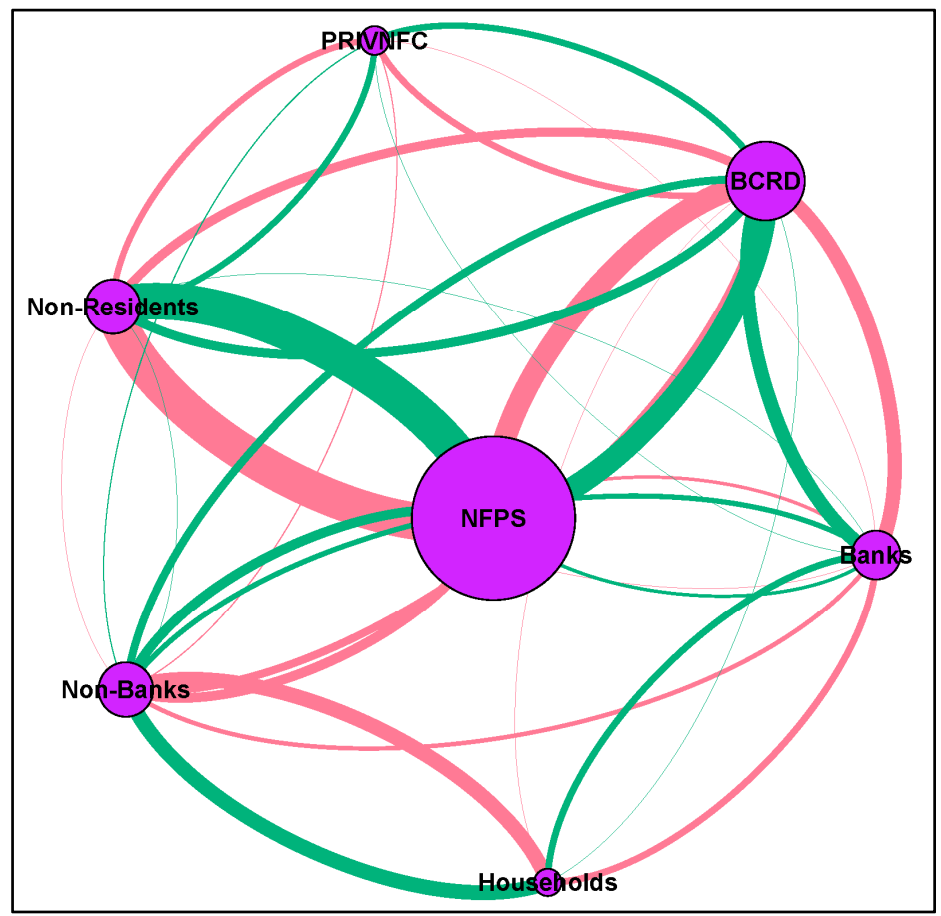

Moreover, given the financial interlinkages in the economy, we can infer how a shock related to the external funding of the government (e.g. increase in interest rate, sharp peso depreciation, or even a sudden stop on financial inflows) could adversely affect the balance sheets of the other sectors. This is especially evident for the financial sector. For example, inability of government to borrow from the international market may affect its capability to service the debt, both domestic and external. In the case of the banking system, this could result in a deterioration in the asset quality of the banks that are exposed to government lending, especially if we take into account the high concentration of such lending. In turn, the weakening of banks' financial position may constrain banks to lend to the rest of the economy, resulting in an overall economic slowdown. The slowdown of the economy could then worsen the financial position of the private sector, and feed back to banks. Potential distress in the NFPS would also affect the already weak financial position of BCRD by further increasing the quasi-fiscal deficit, and thus complicating the monetary policy framework. Also, since the pension funds pass a large portion of households' savings to government bonds, the indirect exposure of the households to the sovereign increases.

\section{Conclusions}

The BSA is a very useful tool for analyzing the macroeconomic impact of financial imbalances. One of its most important features is that it provides detailed information on the composition of the balance sheets of the main sectors of a given economy, and as such helps reveal vulnerabilities and interlinkages that can be hidden in the consolidated country balance sheet. While the level of detail that it provides is its main strength, it is also its Achilles heel, since it depends on adequate and timely data provision by all the sectors involved. 
Applying the BSA to the Dominican Republic, we noted that the overall balance sheet of the economy deteriorated over the last ten years. Such worsening is almost completely driven by the NFPS in response to fiscal deficits, and its reliance on both domestic financial sector and external sector funding has increased. Deterioration is especially pronounced in foreign currency. The financial position of the other sectors of the economy slightly improved and remains broadly solid, although some pockets of vulnerabilities exist. Despite the currency mismatch, the capital structure of the economy has improved as it relies more on equity than on debt instruments. Liquidity risks declined, given the increase of international reserves, longer maturities on government borrowing, as well as an increase of banks and private sector liquid assets in FX.

The financial balance sheet of the combined corporate sector and households appears sound. The sector has strong positive net financial position both in domestic and in foreign currency. Within the domestic financial system, households maintained a strong position in foreign currency, and strengthened their position in domestic currency, as contributions to pension funds increased. At the same time, while the corporate sector has a debtor position in foreign currency against banks, it is being hedged by creditor position of overall nonfinancial private sector against nonresidents. The assessment should be taken with a caution, given that we cannot distinguish between corporate and household assets abroad, and we do not have enough information if the assets abroad are indeed used as a hedge for domestic lending.

The overall financial system does not seem to present major vulnerabilities. Banks are mostly financed through deposits of the private sector and pension funds. Lending to the private sector has been steadily increasing, in line with financial deepening. However, exposure to the public sector in FX increased and is mostly concentrated in the largest bank in the system, which is also state-owned. The pension funds recorded strong growth, reflecting the gradual increase of contributions. An underdeveloped capital market and a tight regulatory framework, on the other hand, makes pension funds invest mostly in public sector debt and banks deposits.

Finally, the country's negative foreign currency position is mainly a result of the accumulation of external liabilities by the public sector. Such a large foreign currency exposure coupled with a devaluation of the Dominican peso would have an adverse impact on this sector's balance sheet. Given the financial linkages among the sectors in the economy and their indirect exposure to exchange rate risks trough the public sector, an external shock would have an amplified effect. Favorable maturity composition of the external debt, on the other hand, could play as an important buffer in such scenario.

Despite the economic growth was very strong in the last ten years, the identified vulnerabilities in the public sector balance sheet pose risks. From the policy perspective, this analysis underlines the importance of sound debt management and continued fiscal consolidation. Such policies would minimize the risks that mismatches in the public sector balance sheet be amplified and affect the stability of the economy. This is particularly relevant if we take into account the risks that lie ahead with monetary policy normalization in the United States and possible shift in market sentiment. The identified currency mismatches also indicate the need to further build foreign international reserves. Promoting the 
development of domestic bond market would allow private sector and financial institutions to diversify their portfolio and reduce the exposure to a single sector. 


\section{ANNEXES}

Annex I. Dominican Republic BSA Matrix

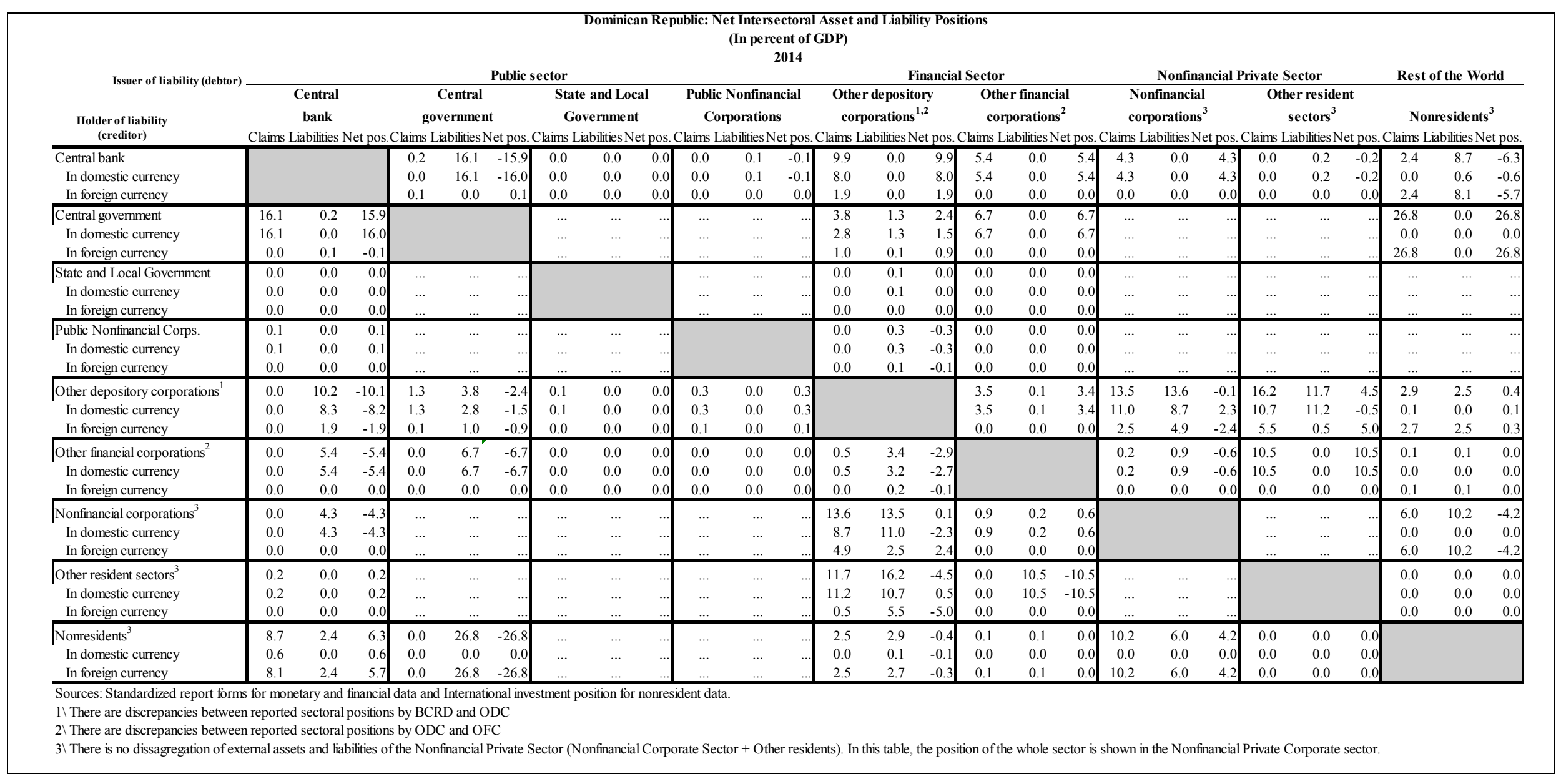


Annex II. Dominican Republic Net Financial Positions

Annex II, Figure 1. Sector's Net Financial Positions vis-à-vis the rest of the Economy
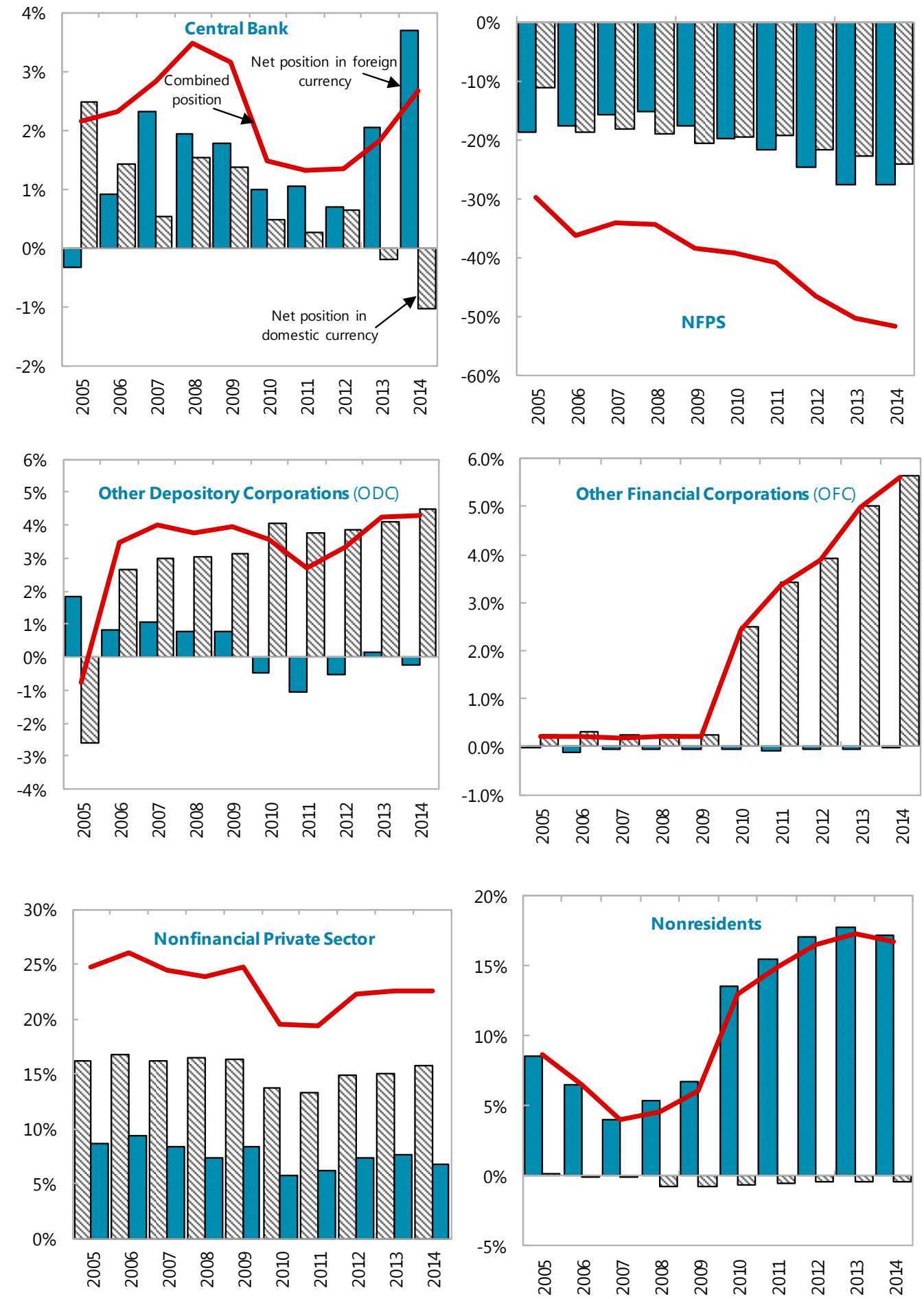

Sources: SRF \& IP and Authors' calculations.

1/ Total financial assets minus total financial liabilities. It does not include FDI-related Assets and Liabilities. 
Annex II, Figure 2. Sector's Net Financial Positions vis-à-vis Nonresidents By currency (In percent of GDP)
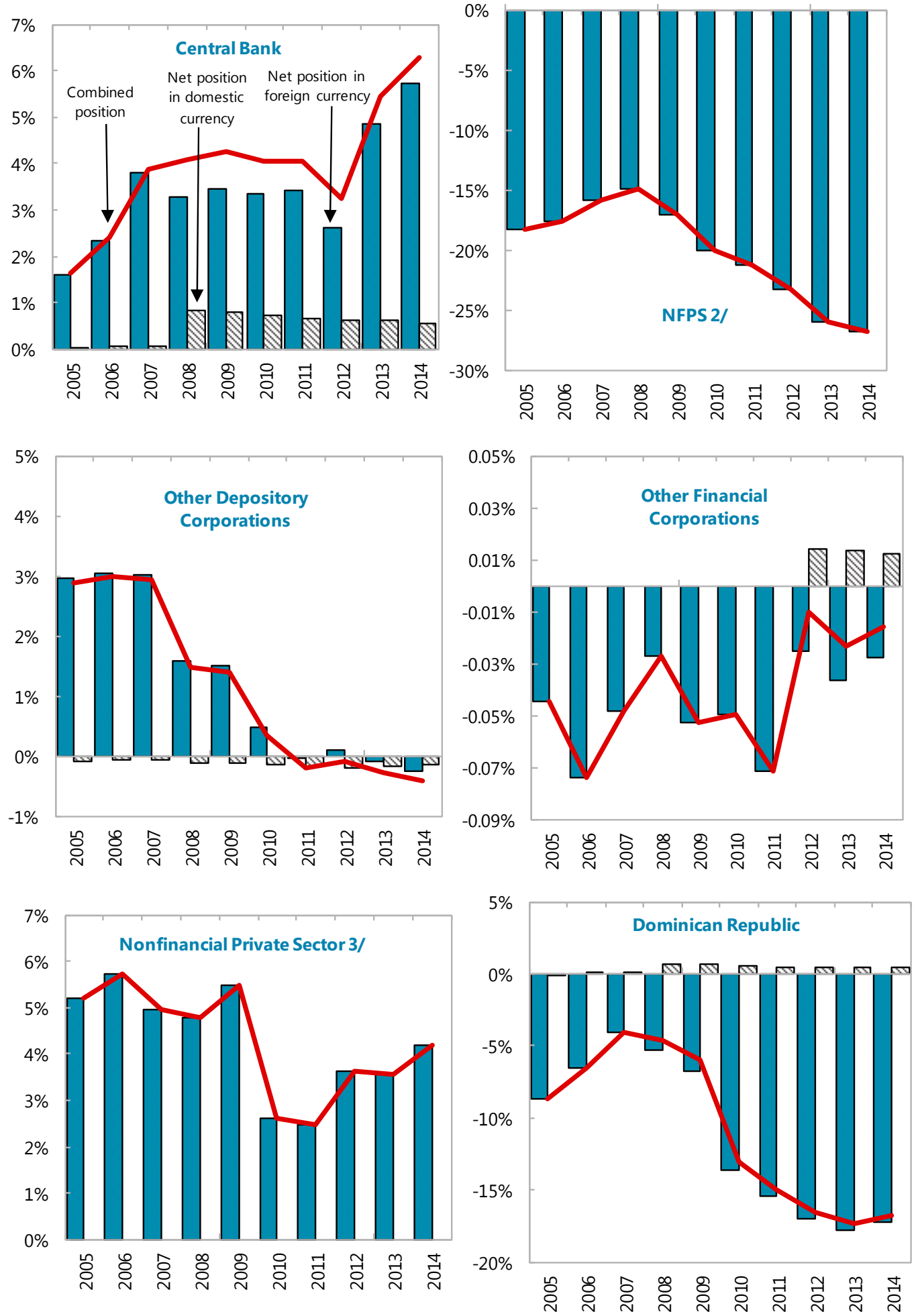

Sources: SRF \& IIP and Authors' calculations

$1 /$ It does not include FDI-related Assets and Liabilities.

2/ Net position in domestic currency (zero or negligible)

3/ Nonfinancial Corporations + Households. Net position in domestic currency is negligible. 
Annex II, Figure 3. BCRD Net Financial Position vis-à-vis the rest of the Economy By currency (In percent of GDP)
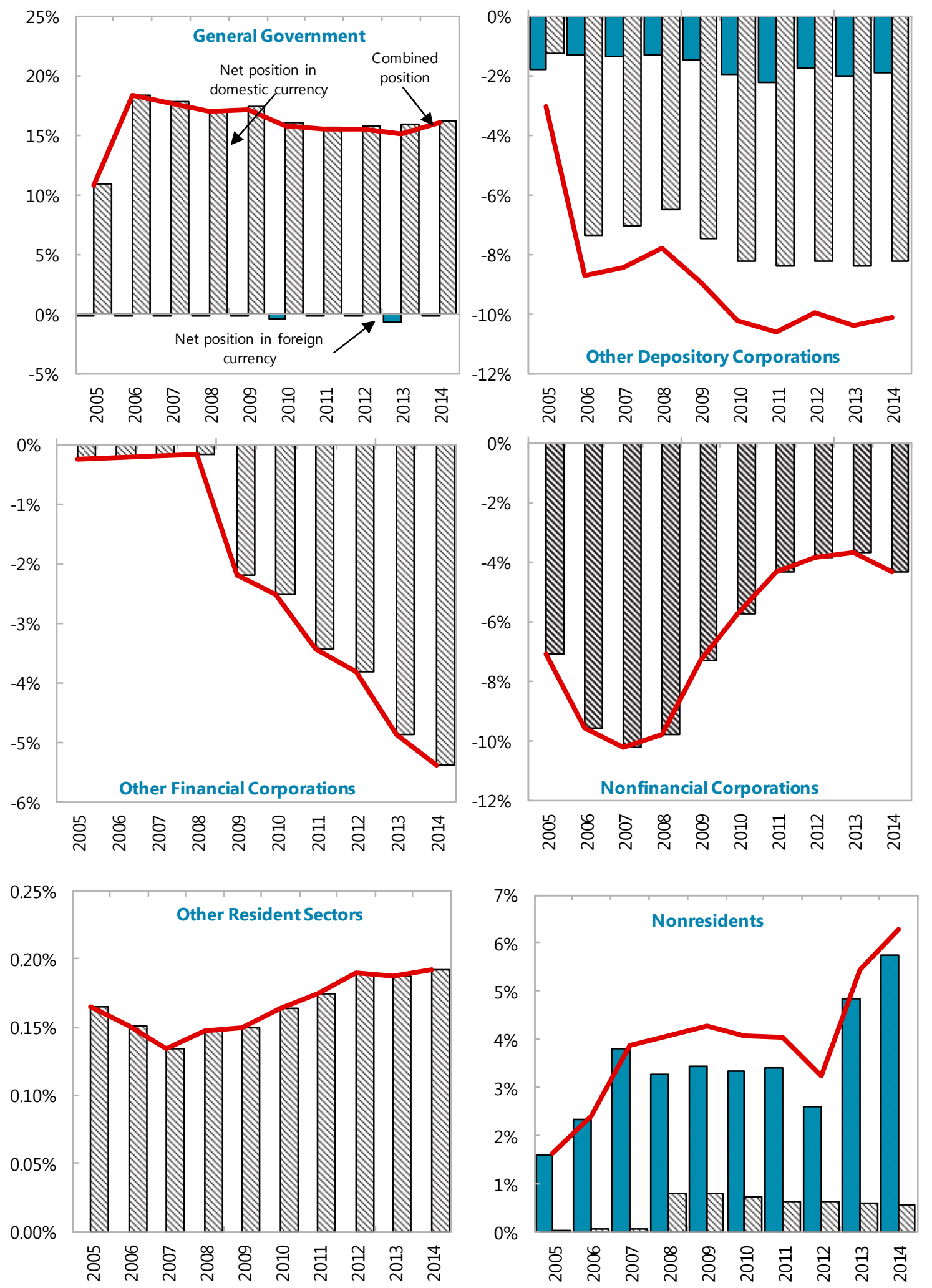

Sources: SRF and Authors' calculations. 
Annex II, Figure 4. ODC Net Financial Position vis-à-vis the Public Sector

By currency (In percent of GDP)
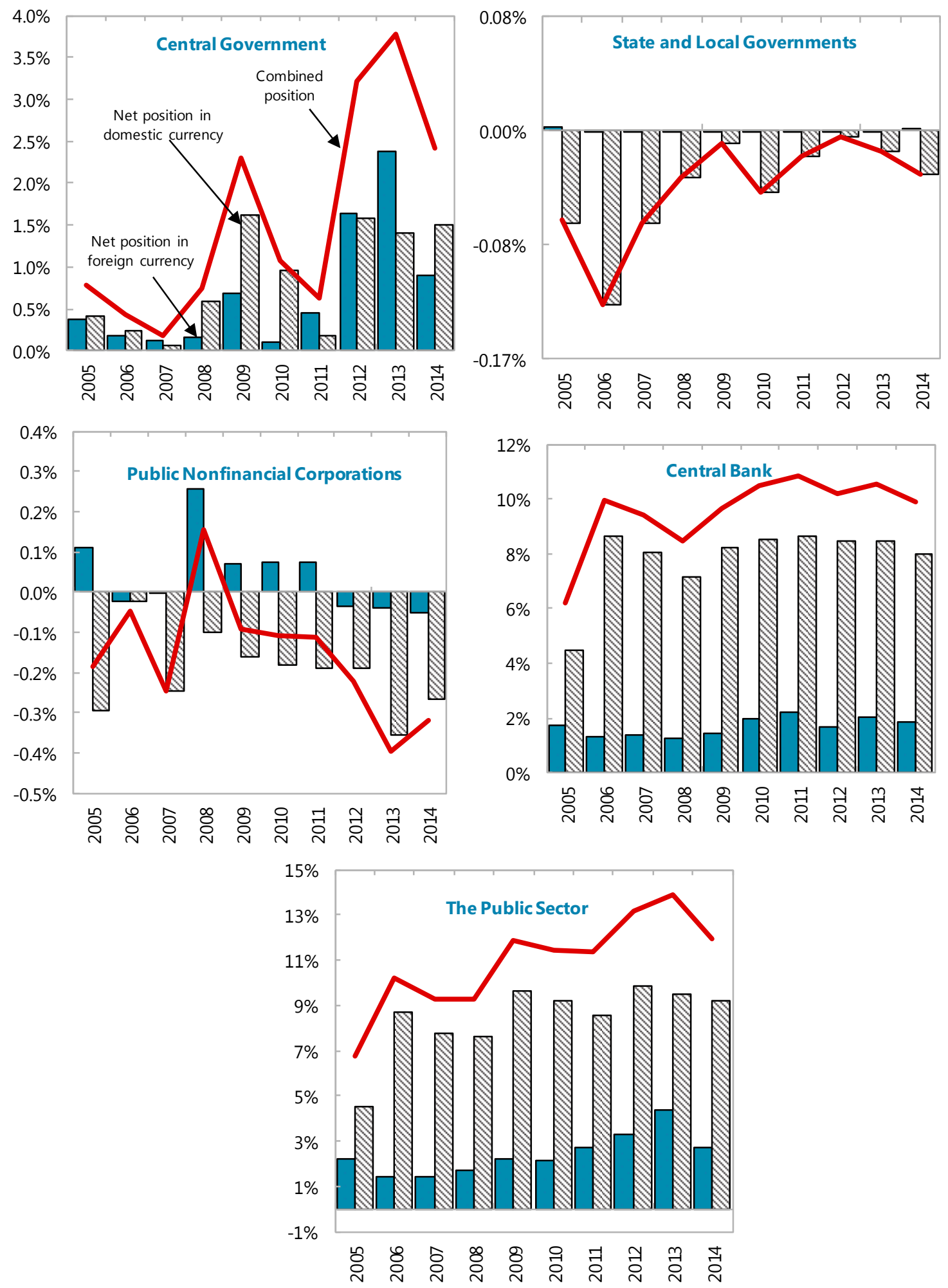

Sources: SRF and Authors' calculations. 
Annex II, Figure 5. ODC Net Financial Position vis-à-vis the rest of the Economy By currency (In percent of GDP)
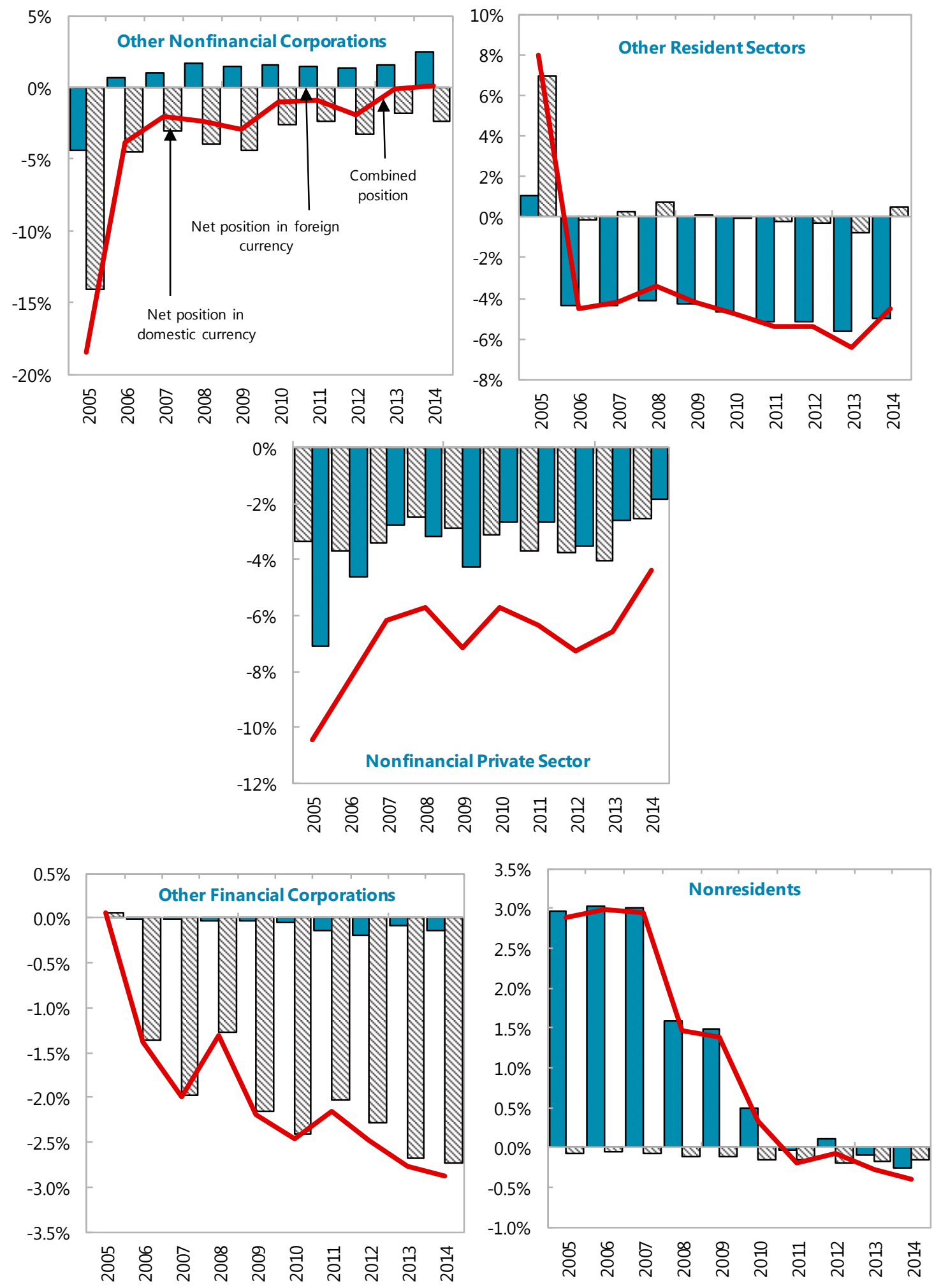

Source: SRF and Authors' calculations. 
Annex II, Figure 6. Nonfinancial Corporations Net Financial Position vis-à-vis the Financial System

By currency (In percent of GDP)
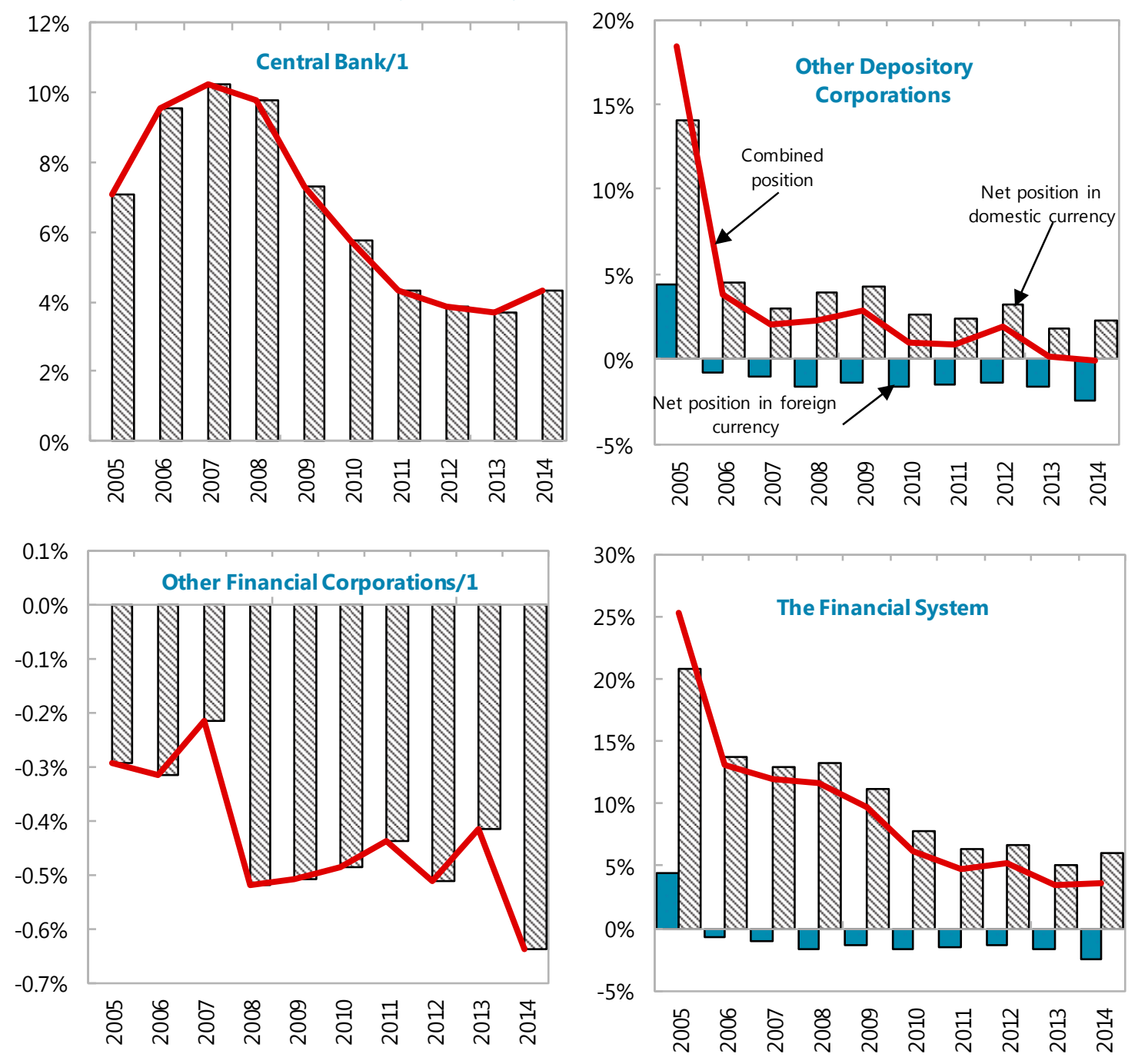

Sources: SRF and Authors' calculations.

1 / There is no exposure to financial instruments in foreign currency. 
Annex II, Figure 7. Other Residents (Households) Net Financial Position vis-à-vis the Financial System

By currency (In percent of GDP)
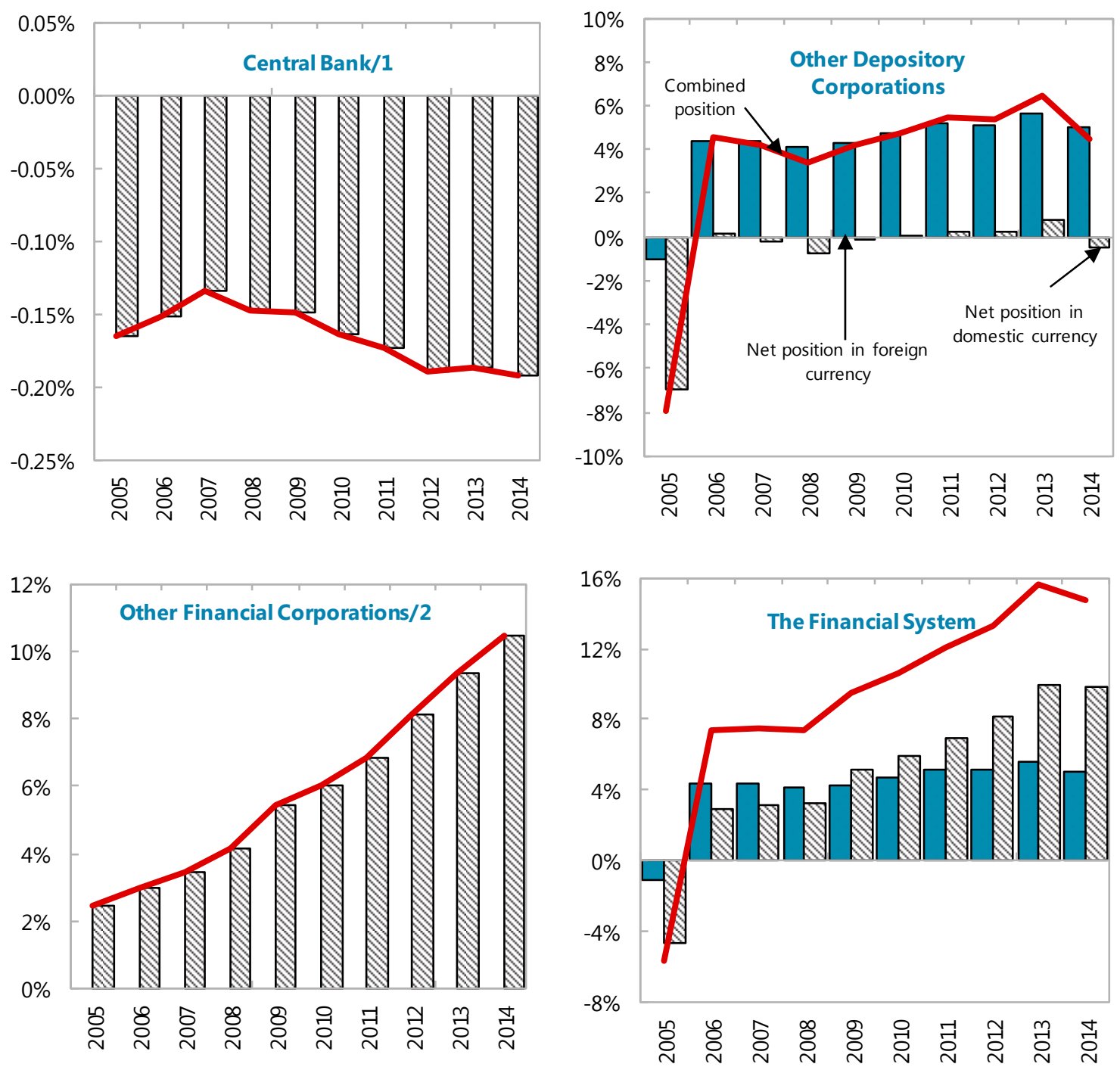

Sources: SRF and Authors' calculations.

$1 / \ln 2005$, the exposure to financial instruments in foreign currency is negligible, after that is zero.

2 / There is no exposure to financial instruments in foreign currency. 
Annex II, Figure 8. Nonfinancial Private Sector Net Financial Position vis-à-vis the rest of the Economy

By currency (In percent of GDP)
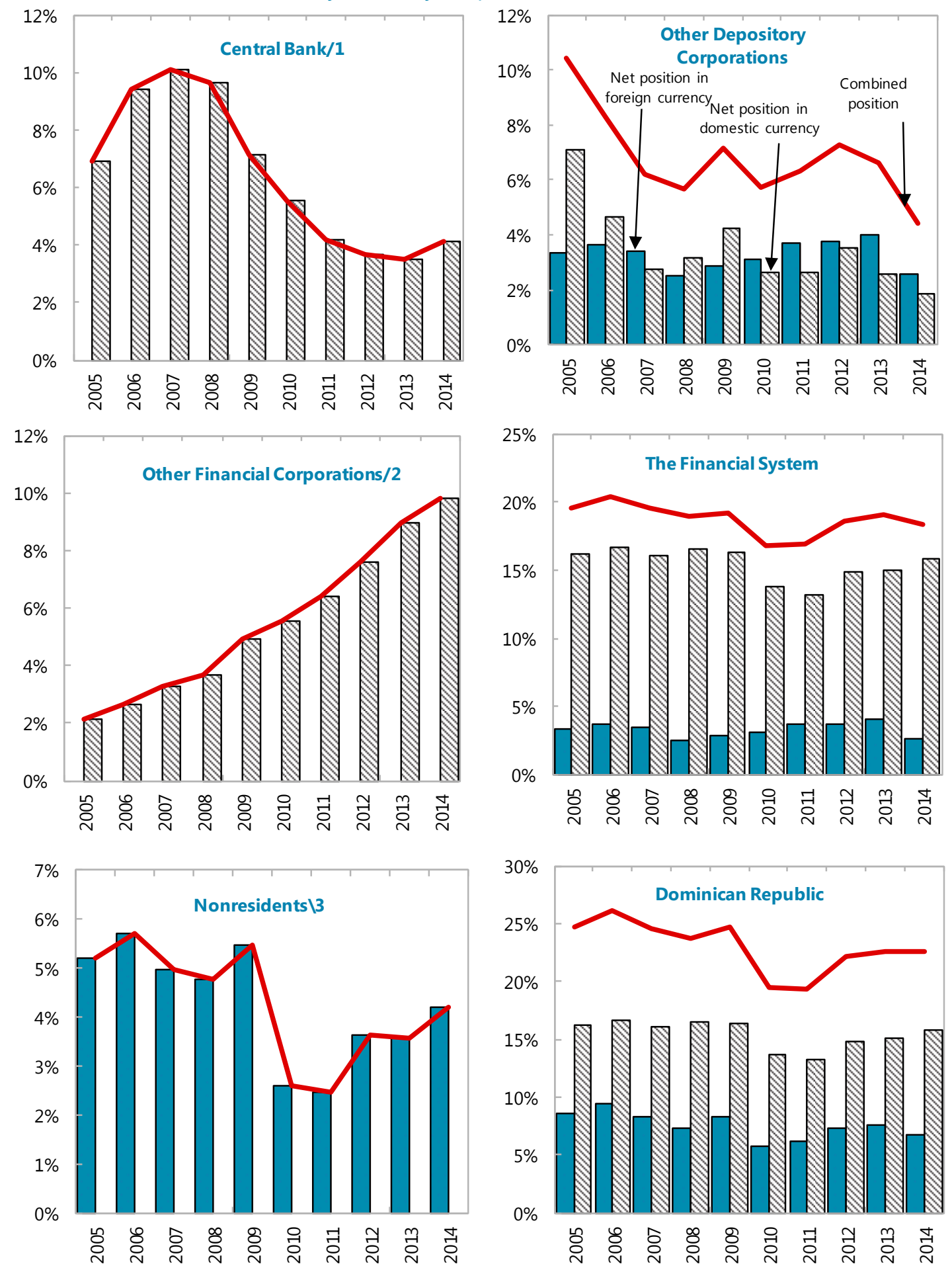

Sources: SRF, IIP and Authors' calculations.

$1 /$ In 2005, the exposure to financial instruments in foreign currency is negligible, after that is zero.

$2 /$ There is no exposure to financial instruments in foreign currency.

$3 /$ There is no reported exposure to financial instruments in domestic currency. 


\section{REFERENCES}

Allen Mark, Rosenberg Christoph, Keller Christian, Setser Brad, and Roubini Nouriel, 2002, "A Balance Sheet Approach to Financial Crisis", IMF Working Paper WP/02/21, December (Washington, D.C.: International Monetary Fund).

Amo-Yartey Charles. 2012, "Barbados: Sectoral Balance Sheet Mismatches and Macroeconomic Vulnerabilities" IMF Working Paper WP/12/31, December (Washington, D.C.: International Monetary Fund).

Calvo Guillermo and Reinhart Carmen, 2000, "Fear of Floating" NBER Working Paper No. 7993, November 2000 (Cambridge, MA, National Bureau of Economic Research).

Cavallo Michele, Kisselev Kate, Perri Fabrizio and Roubini Nouriel, 2005: "Exchange rate overshooting and the costs of floating" Federal Reserve Bank Of San Francisco, Working Paper Series, May 2005

Cepsedes Luis Felipe, Chang Roberto and Velasco Andres, 2000, "Balance Sheet and Exchange Rate Policy", NBER Working Paper No. 7840, August 2000 (Cambridge, MA, National Bureau of Economic Research).

Dornbusch Rudi 2001, “A Primer on Emerging Market Crisis”, NBER Working Paper No. 8326, June 2001 (Cambridge, MA, National Bureau of Economic Research).

Gertler Mark, Gilchrist Simon, and Natalucci Fabio, 2003 "External Constraints On Monetary Policy and The Financial Accelerator" NBER Working Paper No. 10128, December 2003 (Cambridge, MA, National Bureau of Economic Research).

Imam Patrick and Köhler Rainer, 2010 "Balance Sheet Vulnerabilities of Mauritius During a Decade of Shocks" IMF Working Paper WP/10/148, June (Washington, D.C.: International Monetary Fund).

Iyabo Masha, 2009, "The Global financial crisis and adjustments to shocks in Kenya, Tanzania, and Uganda: a balance sheet analysis perspective" (Washington, D.C.: International Monetary Fund, 2009).

IMF 2002,” The Dominican Republic Stabilization, Reform, and Growth" IMF Occasional Paper 206, January (Washington, D.C.: International Monetary Fund).

IMF 2004, Thailand: Selected Issues, IMF Country Report No. 04/1 (Washington, D.C.: International Monetary Fund).

IMF 2004, "Debt-Related Vulnerabilities and Financial Crises-An Application of the Balance Sheet Approach to Emerging Market Countries" (Washington, D.C.: International Monetary Fund, July 2004). 
IMF 2010, Dominican Republic: Staff Report for the 2009 Article IV Consultation and Request for a Stand-By Arrangement, IMF Country Report No. 10/135 (Washington, D.C.: International Monetary Fund).

IMF 2013, Guatemala, 2013, Selected Issues and Analytical Notes, IMF Country Report No. 13/248, August (Washington, D.C.: International Monetary Fund).

IMF 2015, Costa Rica, 2015, Selected Issues and Analytical Notes, IMF Country Report No. 15/30, February (Washington, D.C.: International Monetary Fund).

IMF 2015, "Balance Sheet Analysis in Fund Surveillance” IMF Policy Paper, June (Washington, D.C.: International Monetary Fund).

Jeanne Olivier, Zettelmeyer Jeromin 2002, “Original Sin”, Balance Sheet Crises and the Roles of International Lending”, IMF Working Paper WP/02/234, December (Washington, D.C.: International Monetary Fund).

Krugman Paul 1999, "Balance Sheets, the Transfer Problem, and Financial Crises" Journal of International Tax and Public Finance, Volume 6, pp 459-472 (Kluwer Academic Publishers, Boston).

Milesi Ferretti, G. M. and Razin, Assaf (1996). "Current Account Sustainability”, Princeton Studies in International Finance, No. 81, Princeton University.

Milesi Ferretti, G. M. (2006). "How Much Progress Has Been Made in Addressing Global Imbalances?" in World Economic Outlook (Washington, D.C.: International Monetary Fund).

Lee Jaewoo, Ostry Jonathan David, Prati Alessandro, Ricci Luca Antonio and Milesi-Ferretti Gian-Maria, 2008 “Exchange Rate Assessments: CGER Methodologies", IMF Occasional Paper No. 261, April (Washington, D.C.: International Monetary Fund).

Lima Juan Manuel, Montes Enrique, Varela Carlos, and Wiegand Johannes 2006, "Sectoral Balance Sheet Mismatches and Macroeconomic Vulnerabilities in Colombia, 19962003," IMF Working Paper WP/06/5, January (Washington, D.C.: International Monetary Fund).

Mathisen Johan and Pellechio Anthony 2006, "Using the Balance Sheet Approach in Surveillance: Framework, Data Sources, and Data Availability", IMF Working Paper WP/06/100, April (Washington, D.C.: International Monetary Fund).

Reinhart Carmen, Rogoff Kenneth, and Savastano Miguel 2003, "Addicted to Dollars", NBER Working Paper No. 10015, October 2003 (Cambridge, MA, National Bureau of Economic Research).

Rodriguez Carlos Alfredo, 1992 "Money and Credit under Currency Substitution”, IMF Working Paper WP/92/99, November (Washington, D.C.: International Monetary Fund). 
Swiston Andrew, Frantischek Florencia, Gajdeczka Przemek, and Alexander Herman, 2014 "Central Bank Financial Strength in Central America and the Dominican Republic", IMF Working Paper WP/14/87, May (Washington, D.C.: International Monetary Fund). 